Purdue University

Purdue e-Pubs

Open Access Dissertations

Theses and Dissertations

January 2015

\title{
Detecting Earnings Information in Repurchase Announcements using the Luck of the (Double) Irish
}

William O'Brien

Purdue University

Follow this and additional works at: https://docs.lib.purdue.edu/open_access_dissertations

\section{Recommended Citation}

O'Brien, William, "Detecting Earnings Information in Repurchase Announcements using the Luck of the (Double) Irish" (2015). Open Access Dissertations. 1137.

https://docs.lib.purdue.edu/open_access_dissertations/1137

This document has been made available through Purdue e-Pubs, a service of the Purdue University Libraries. Please contact epubs@purdue.edu for additional information. 


\section{PURDUE UNIVERSITY \\ GRADUATE SCHOOL \\ Thesis/Dissertation Acceptance}

This is to certify that the thesis/dissertation prepared

By William O'Brien

Entitled

Detecting Earnings Information in Repurchase Announcements using the Luck of the (Double) Irish

For the degree of Doctor of Philosophy

Is approved by the final examining committee:

Mara Faccio

Chair

Byoung Hwang
Huseyin Gulen

John McConnell

To the best of my knowledge and as understood by the student in the Thesis/Dissertation Agreement, Publication Delay, and Certification Disclaimer (Graduate School Form 32), this thesis/dissertation adheres to the provisions of Purdue University's "Policy of Integrity in Research" and the use of copyright material.

Approved by Major Professor(s): Mara Faccio

Approved by: Mark Bagnoli

$9 / 23 / 2015$

Head of the Departmental Graduate Program

Date 


\title{
DETECTING EARNINGS INFORMATION IN REPURCHASE ANNOUNCEMENTS USING THE LUCK OF THE (DOUBLE) IRISH
}

\author{
A Dissertation \\ Submitted to the Faculty \\ of \\ Purdue University \\ by \\ William J. O’Brien \\ In Partial Fulfillment of the \\ Requirement for the Degree \\ of \\ Doctor of Philosophy
}

December 2015

Purdue University

West Lafayette, Indiana 
For Laura. 


\section{ACKNOWLEDGMENTS}

Thanks to my advisor Mara Faccio, along with Alice Bonaimé, Matthew D. Cain, David Denis, Huseyin Gulen, Jeremiah Harris, Kate Holland, Scott Hsu, Byoung-Hyoun Hwang, Yeejin Jang, Charles Johnston, Steven Krull, John McConnell, Stephen McKeon, Ralitsa Petkova Warner, Steven Sibley, Justin Tobias, Jin Xu, Deniz Yavuz, Chengxi Yin, Marc Zenner, Xiaoyan Zhang, and seminar participants at Purdue University, Syracuse University, The University of Georgia, The University of Illinois at Chicago, The University of Missouri, and The University of Wisconsin-Milwaukee for their helpful comments. 
TABLE OF CONTENTS

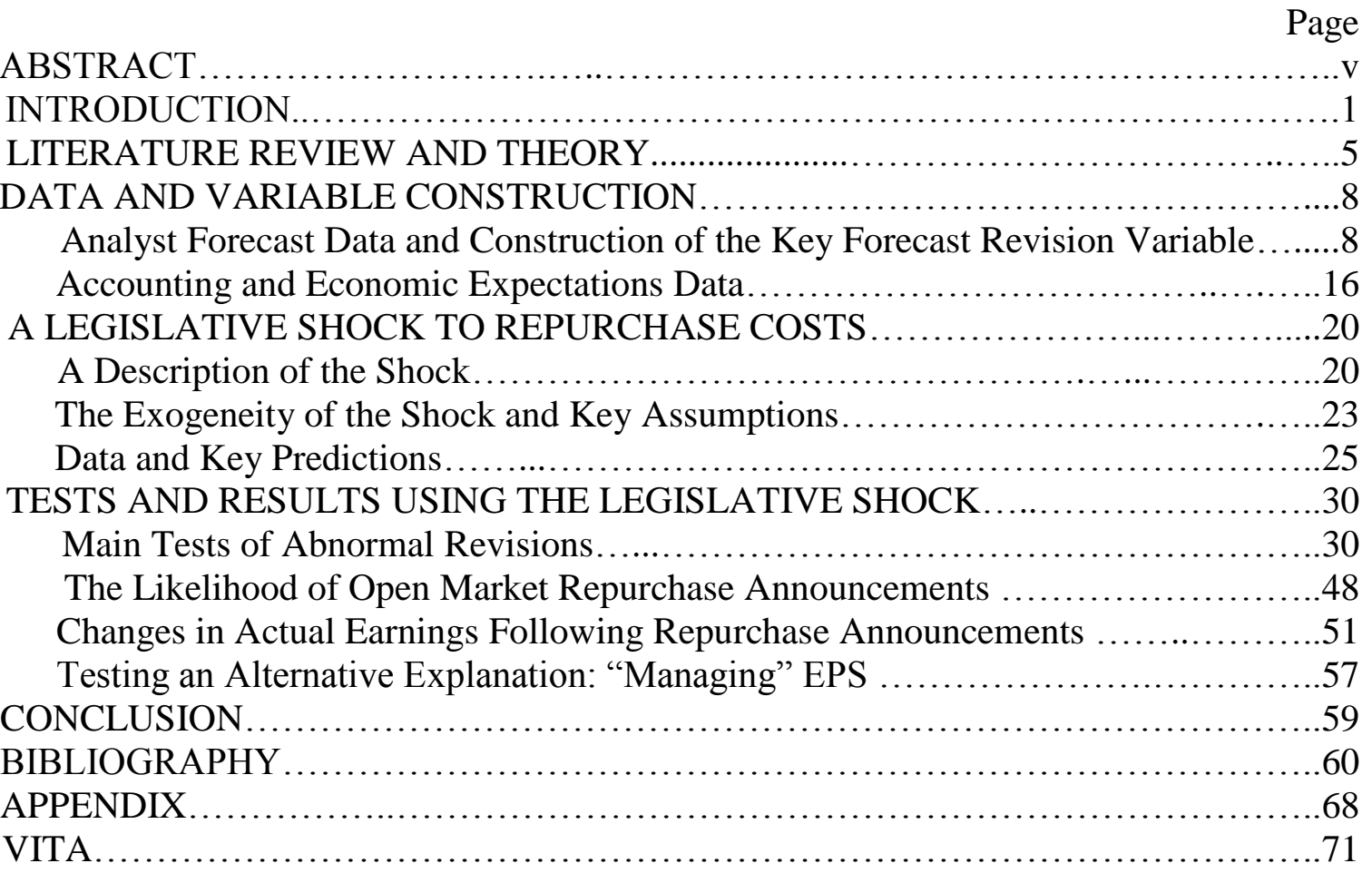




\begin{abstract}
O’Brien, William J., Ph.D., Purdue University, December 2015, Detecting Earnings Information using the Luck of the (Double Irish). Major Professor: Mara Faccio.

Previous studies disagree about whether open market repurchase announcements contain information about earnings expectations. Using a regulation that made tax haven-using firms' repurchases more costly as a quasi-natural experiment, I find positive postrepurchase-announcement revisions in earnings expectations for firms using "Double Irish" offshore tax avoidance structures. These results are robust to falsification tests, different types of tax havens, and changes in forecasted and actual earnings. "Double Irish" firms announce fewer repurchase programs than other firms after the regulation, consistent with an increase in their repurchasing costs. These results suggest that certain costly repurchases are announced when outsiders underestimate future earnings.
\end{abstract}




\section{CHAPTER 1 INTRODUCTION}

Open market repurchases (hereafter "OMRs"), where firm managers announce their intention to buy back a portion of publicly traded firm shares at market prices, are perhaps the most popular modern payout method in the U.S. (Grullon and Michaely (2004), Skinner (2008)). This study investigates whether announcements of OMR programs contain new information about earnings expectations. I examine this question using a 2007 regulatory change (novel to payout policy studies, to the best of my knowledge) that affected certain firms' repurchase costs and therefore plausibly altered their repurchase motivations and decisions.

While many theorists have suggested a link between firm payouts and favorable earnings information conveyed by the payouts, especially in payouts that are costly for firms, past empirical studies of OMR announcements have found conflicting results. ${ }^{1}$ Using changes in repurchaser earnings (adjusted for changes in matched, non-repurchaser earnings) as a proxy for earnings expectations, Jagannathan and Stephens (2003) and Grullon and Michaely (2004) find inconclusive results, while Lie (2005) and Billett and $\mathrm{Yu}$ (forthcoming) find evidence of average post-announcement operating improvements in certain subsamples of firms. However, Gong, Louis, and Sun (2008) show that some postOMR-announcement operating improvements may result from downward earnings management preceding the announcement.

Relatively fewer studies have examined earnings forecast revisions after OMR announcements. To the extent that analyst forecasts are informative about actual future earnings, forecast revisions represent an appealing alternative proxy for changes in

\footnotetext{
${ }^{1}$ Studies that propose earnings signaling models of payouts include Bhattacharya (1979), Vermaelen (1981), John and Williams (1985), Miller and Rock (1985), and Ofer and Thakor (1987).
} 
earnings expectations. For example, Devos, Kadapakkam, and Krishnamurthy (2009) discuss how forecast revisions are unaffected by survivorship bias and future earningsinfluencing events. Analysts also remove impacts from earnings management to provide their clients with more useful information (Louis, Sun, and Urcan (2013)). Interestingly, Jagannathan and Stephens (2003), Grullon and Michaely (2004), and Peyer and Vermaelen (2009) all find evidence of downward average earnings per share (EPS) forecast revisions after OMR announcements. These results suggest either that OMR announcements convey information about worse-than-expected earnings or that managers are timing these OMR announcements exceptionally poorly. ${ }^{2}$

I begin by offering an explanation for these counterintuitive results. I find that the evidence of negative average forecast revisions in past studies was likely the result of either 1) an overall downward bias in earnings forecast revisions across all firms (as documented by O'Brien (1988) and Brous (1992)) or 2) forecast bias-correction procedures that inadvertently introduced new biases. Using a novel measure of forecast revisions that adjusts for these biases, I find no evidence of downward revisions in earnings expectations, on average, in a 28-year sample of OMR announcements.

Next, I identify open market repurchase programs that are likely to be costly for firms and test whether these repurchase program announcements contain information about earnings expectations. My tests of these OMR announcements utilize a quasi-natural experiment: an unexpected legislative shock related to the practice of using pre-tax corporate profits stored in overseas tax havens for repurchases. Traditionally, domestic tax payments on overseas cash holdings were delayed until the money was "repatriated" back to the U.S. However, some firms avoided these repatriation-related taxes by initiating repurchase programs through their foreign subsidiaries, returning the funds directly to shareholders without paying U.S. taxes. In reaction to this, in May 2007 the IRS issued Notice 2007-48, which prevented U.S. firms from continuing this practice. ${ }^{3}$ This forced tax

\footnotetext{
${ }^{2}$ While Bartov (1991) finds evidence of positive earnings information using forecast revisions after OMR announcements, the sample used is small and the author himself suggests that the overall evidence consistent with earnings signals conveyed by the announcements is weak.

${ }^{3}$ Johnston, David Cay, "I.R.S. Moves to Close Tax Shelter Shortly After I.B.M. Uses It to Save \$1.6 Billion", The New York Times June 2007. More detail on the specific IRS Notice can be found in Pauls and Zeswitz (2011).
} 
haven-using firms to fund repurchases by repatriating and paying taxes on offshore, untaxed profits or using other cash sources (new debt, domestic cash reserves, etc.) that would constrain the firms from maximizing future offshore profit transfers.

My tests focus on firms using a complex and effective method of tax avoidance called the "Double Irish with a Dutch Sandwich." In this method, U.S. firms use an Irish subsidiary to store firm patents; pre-tax profits are then diverted to this Irish subsidiary as "patent royalties." Other foreign subsidiaries are used to avoid further taxation from Irish tax authorities. By closing the repurchase-based repatriation "loophole" described above, the 2007 regulation increased the cost of repurchasing for these firms. I hypothesize that a firm's willingness to bear these repurchase-related costs may indicate that outsiders are underestimating the firm's future earnings.

Consistent with this hypothesis, I find that average post-OMR-announcement earnings expectation revisions are positive for firms likely to be using the "Double Irish" technique, but only after the IRS reform. In difference-in-difference tests, I also find a significantly higher change in "Double Irish" firms' post-OMR-announcement revisions (compared with other firms' post-OMR-announcement revisions) from before to after the regulation. I also use triple difference specification that compare this difference-indifference measure to the same measure in non-OMR-announcing periods. This specification is a falsification test designed to mitigate the possibility that the significantly higher forecast revisions found in "Double Irish" firms after the regulation are present in all monthly observations for these firms (rather than just after repurchase announcements). These tests find that the difference-in-difference results are specific only to periods after an OMR is announced. Importantly, these results are robust to both bias-adjusted and unadjusted measures of forecast revisions. I also find evidence of positive earnings information in a larger sample of firms with a subsidiary in any country classified as a tax haven.

Other test results are consistent with the IRS reform impacting the likelihood of initiating OMR programs. As would be expected with a higher cost of repurchasing, "Double Irish" firms announce fewer programs (compared with other firms) after the regulation. Additional tests using propensity score matched changes in actual earnings 
produce similar results and inferences to tests of forecasted earnings. Finally, results in the key forecast revision tests cannot be explained by any "accretive" effects of repurchasing (i.e. mechanical increases in EPS increases resulting from a diminished number of shares outstanding). Taken together, these results suggest that firms with costly repurchases may announce OMR programs when earnings are underestimated by outsiders.

This study contributes to a number of areas of finance literature. I construct a novel measure of analyst forecast revisions that provides an explanation for the negative average revisions found in past OMR studies. I also find evidence of positive earnings revisions in subsamples of OMR-announcing firms using a unique shock to repurchase costs. To my knowledge, this is the first OMR study to provide evidence of both positive forecasted and actual earnings changes in any subsample of repurchase-announcing firms, the first to provide evidence of the link between costs and signals found in traditional signaling models, and the first to utilize this particular legislative shock. This paper also adds an important facet to our understanding of the use of tax havens by U.S. firms: if a firm is keeping untaxed profits offshore, OMR program announcements may be not only less frequent than expected but also an indication of better-than-expected future earnings.

The paper is organized as follows. Section I reviews payout policy literature and repurchase hypotheses. Section II discusses data and variables used in the paper. Section III explains the repurchase cost shock. Section IV present results of tests using that shock. Section V concludes. 


\section{CHAPTER 2 LITERATURE REVIEW AND THEORY}

The traditional signaling hypothesis for payouts relies on information asymmetries that cause insiders and outsiders to value a firm differently. Under this hypothesis, firm managers who believe that outsiders are undervaluing the firm explicitly provide a positive signal about better-than-expected upcoming earnings by initiating a new payout to shareholders. Closely related is the undervaluation hypothesis, where managers perceive the firm's shares to be undervalued for rational (i.e. asymmetric information-based) and/or irrational (i.e. market sentiment-based) reasons. Both hypotheses suggest that managers value the firm more highly than outsiders, but this valuation difference is not necessarily based on earnings expectations in the undervaluation hypothesis. Although a number of studies find evidence of improved earnings following tender offers (Vermaelen (1981), Dann, Masulis, and Mayers (1991), and McConnell and Lie (1998)), the evidence using OMR announcements is more mixed, as discussed in the introduction.

What do signaling explanations for repurchases actually predict? Consider the following simple model of firm valuation, adapted from Modigliani and Miller (1966):

$$
\text { Value of Firm }=P V\left(E\left[C F_{\text {assets in place }}\right]\right)+P V\left(E\left[C F_{\text {opportunities }}\right]\right)
$$

The market's valuation of a firm is the sum of the present values of two sources of expected cash flows. The first source is cash flows from the firm's assets in place (i.e. cash flows from current operations), while the second source is cash flows from growth opportunities. (Similar models are used in payout studies by Miller and Rock (1985) and Lang and Litzenberger (1989).)

Signaling explanations concern the first source of expected cash flows in equation (1). Although payouts in signaling models are costly for the firm, the new information signaled about cash flows from assets in place results in an overall increase in the market's 
valuation of the firm. While the traditional signaling hypothesis has been discounted in practitioner surveys (Brav et al. (2005)) and even in studies that find evidence of positive post-OMR announcement changes in earnings (Lie (2005)), the more general undervaluation hypothesis has found greater support. For example, Brav et al. (2005) note that practitioners associate both undervaluation and earnings information with repurchases. ${ }^{4}$ More formally, the main prediction of both signaling explanations and an earnings-related undervaluation story can be expressed as a testable hypothesis: If OMR announcements convey positive information about earnings, there should be upward revisions in expected cash flows from assets in place (on average) after those announcements.

This prediction is unique to these two repurchase explanations. For example, the free cash flow hypothesis (Jensen (1986)) suggests that if managers don't always work in the best interests of shareholders (Jensen and Meckling (1976)), increasing payouts to shareholders using the firm's excess cash will reduce a managers' ability to invest in valuedestroying projects. However, to my knowledge no studies argue that these types of payouts should be followed by increases in cash flows from assets in place; they should instead affect either expected longer-term cash flows from growth opportunities (by removing the cash that enables sub-optimal investments) or affect the discount rates applied to future cash flows by signaling a decrease in a firm's systematic risk (leaving undiscounted earnings expectations unchanged). Other payout explanations do not link the OMR announcements themselves to increases in expected cash flows from assets in place. ${ }^{5}$

Although many repurchase studies use stock returns in their tests, positive postannouncement returns do not necessarily indicate an upward revision in cash flows from assets in place, nor is this result uniquely attributable to signaling or earnings-related

\footnotetext{
${ }^{4}$ More specifically, three of the top five motivations for repurchases listed in Brav et al. (2005) are "market price of our stock (if our stock is a good investment, relative to its true value)", "stability of future earnings" and "(a) sustainable change in earnings."

${ }^{5}$ Other explanations specific to OMRs include defense against takeovers (Bagnoli et al. (1989), Bagwell (1991), and Billett and Xue (2007)), altering leverage ratios (Dittmar (2000)), substitution for dividend payments (Grullon and Michaely (2002)), fulfilling executive stock option grants and preventing dilution (Kahle (2002)), a desire to reverse the negative stock price effects of a competitor's repurchase announcement (Massa et al. (2007)), CEO opportunism (Griffin and Zhu (2010)), a desire to mislead investors (Chan et al. (2010)), and a reaction to diminished product market threats (Hoberg, Phillips, and Prahbala (2014)).
} 
undervaluation explanations. ${ }^{6}$ For example, a repurchase motivated by overinvestment concerns would result in a stock price increase without altering expectations about cash flows from assets in place. In unreported tests I find significantly positive $[-1,+2]$ day announcement returns using a variety of cumulative return measures (raw, marketadjusted, and Fama-French (1993) risk-factor adjusted) in every subsample of OMR announcements examined in this study. Rather than further examine stock returns, I instead follow previous studies (Jagannathan and Stephens (2003), Grullon and Michaely (2004)) that use both near-term earnings and earnings forecasts as proxies for cash flows from assets in place.

\footnotetext{
${ }^{6}$ Many studies find stock price improvements after tender offers (Vermaelen (1984), Comment and Jarrell (1991), D'Mello and Shroff (2000), and Louis and White (2007)) and OMRs and OMR announcements (Ikenberry et al. (1995), Stephens and Weisbach (1998), Jagannathan and Stephens (2003), Peyer and Vermaelen (2009), Babenko, Tserlukevich, and Vedrashko (2012), Billett and Yu (forthcoming), and Dittmar and Field (forthcoming)).
} 


\section{CHAPTER 3 DATA AND VARIABLE CONSTRUCTION}

\section{III.A. Analyst Forecast Data and Construction of the Key Forecast Revision Variable}

Data on U.S. OMR announcements are obtained from the Securities Data Corporation's Mergers and Acquisitions database. I follow Grullon and Michaely (2004) and drop observations where dividends were decreased prior to the announcement (within four quarters), since these repurchases may simply substitute for existing dividends (Grullon and Michaely (2002)). The resulting sample contains 13,506 OMR announcements from 1984-2011.

Monthly split-adjusted data on earnings forecasts are obtained from the I/B/E/S summary file. Due to some implausibly large positive and negative forecast revisions in the data, all I/B/E/S earnings forecast revisions are trimmed at the $1^{\text {st }}$ and $99^{\text {th }}$ percentiles. Additionally, all stocks with a lagged monthly price of less than $\$ 1$ are dropped from the sample. ${ }^{7}$ I obtain data for seven forecast periods available in I/B/E/S: the next four quarters (including the current quarter) and three years (including the current year). Following Grullon and Michaely (2004), I define "Abnormal Forecast Revisions" (AFR) as follows:

$$
A F R_{i, t}=F R_{i, t}-E\left(F R_{i, t}\right) .
$$

$F R$ is the median revision in earnings per share (EPS) for firm $i$ in month $t$, scaled by the lagged monthly stock price of the firm. Price scaling is used to reduce measurement error in the forecasts (Christie (1987)). Since AFR typically has between two and four zeroes after the decimal point, I scale up all AFR measures in the tables by a factor of 1,000 to make the results easier to read.

$E(F R)$ is a firm's "expected" revision in EPS. In their study, Grullon and Michaely (2004) define $E(F R)$ as the average of nearly all available forecast revisions across time for

\footnotetext{
${ }^{7}$ The results and inferences from subsequent tests are similar if these low-priced stocks remain in the sample.
} 
a firm. Using this method, each firm has a unique $E(F R)$ based on their past and future forecast revisions. Brous and Kini (1993) originally used this technique in an attempt to control for an observed correlation between forecast optimism bias and firm size. ${ }^{8}$

However, the forecast revisions for each firm over time are likely to reflect not only any bias related to firm size but also the actual performance of that firm over time. Historically successful firms should be expected to have more positive forecast revisions over time, as analysts are likely to adjust future earnings expectations upward in response to firm success. Ceteris paribus, these firms would have higher average forecast revisions over time than other firms. Successful firms are also more likely to become large firms, in the same way that mutual fund size is linked to past success (Berk and Green (2004)). This raises concerns that the construction of $E(F R)$ described above would result in downwardbiased AFRs in historically profitable firms. This in turn might lead to incorrect inferences in OMR studies, especially if OMR-announcing firms are more historically "successful" in general.

I address this concern by quantifying this size-correlated bias and defining $E(F R)$ only in terms of this bias and the remaining "optimism bias" common to all firms (O'Brien (1988) and Brous (1992)). First, I estimate the following OLS regression in the full I/B/E/S database:

$$
\text { AvgHistRevision }_{i, t}=\alpha+\beta_{1} \text { RankSize }_{i, t}+\beta_{2} \operatorname{UpwardEPS}_{i, t}+\varepsilon_{i, t} .
$$

The dependent variable AvgHistRevision is the average of all price-scaled median forecast revisions for firm $i$ over its entire $\mathrm{I} / \mathrm{B} / \mathrm{E} / \mathrm{S}$ listing period. (This is a close analog of Grullon and Michaely's $E(F R)$ ). The regression decomposes this measure into a size-related component and a performance-related component. In equation (3), RankSize is the percentile rank of firm $i$ 's size (in assets) among all Compustat-listed firms in a particular quarter. Based on the results in Brous and Kini (1993), I expect RankSize to be positively related to AvgHistRevision. UpwardEPS is the fraction of firm $i$ 's year-over-year actual

\footnotetext{
${ }^{8}$ The source of this size-related bias is unclear. $\mathrm{Gu}$ and $\mathrm{Wu}(2003)$ suggest that analysts have strong incentives to issue optimistic initial forecasts for small firms in order to gain access to managers in those firms. This implies that firm size is not directly related to forecast revisions, but instead proxies for analysts using optimistic forecasts to reduce the higher levels of information asymmetry between insiders and outsiders in small firms.
} 
EPS changes over its entire $\mathrm{I} / \mathrm{B} / \mathrm{E} / \mathrm{S}$ listing period that are EPS increases. This measure is designed to capture how often each firm is growing or shrinking in EPS. I expect UpwardEPS to be positively related to AvgHistRevision, since analyst forecast revisions should, to some extent, reflect the actual performance of the firm over time. The percentile measure RankSize is input into the regressions as its decimal equivalent in order to make the coefficient values more comparable to UpwardEPS (both variables now take on continuous values between 0 and 1). I use observations with at least 20 monthly I/B/E/S updates in the regressions. Standard errors are clustered at the firm level.

The coefficients generated by these regressions are shown in Table 1. Both RankSize and UpwardEPS are positive and highly significant in all regressions. Importantly, the coefficients and t-statistics on UpwardEPS are much larger than those on RankSize. This suggests that historical revisions are more strongly correlated with firm performance over time than firm size.

\section{Table 1: Forecast Bias Estimation Regressions}

Caption: This table presents the coefficients and t-statistics from the following OLS regression: $\quad$ AvgHistRevision $_{i, t}=\alpha+\beta_{1}$ RankSize $_{i, t}+\beta_{2}$ UpwardEPS $_{i, t}+\varepsilon_{i, t}$. AvgHistRevision is the average price-scaled median forecast revision for firm i over its entire I/B/E/S listing period. This variable is scaled up by 1,000 in order to make the resulting coefficient estimates more readable. RankSize is the percentile rank of firm i's size (in assets) compared to all other Compustat-listed firms in quarter $t$ and is input into the regressions as its decimal equivalent (i.e. values between 0 and 1) in order to make the coefficient values more comparable to UpwardEPS. UpwardEPS is the fraction of yearover-year increases in firm i's actual EPS (relative to total year-over-year EPS changes) over its I/B/E/S listing period. To reduce noise, firms with fewer than $20 \mathrm{I} / \mathrm{B} / \mathrm{E} / \mathrm{S}$ monthly forecast updates are dropped prior to the OLS estimation. Standard errors are clustered at the firm level. "Time period" refers to the $\mathrm{I} / \mathrm{B} / \mathrm{E} / \mathrm{S}$ forecast period used for each forecast measure ("Quarter + 0" refers to the forecast of the current fiscal quarter as of the time of the repurchase announcement, "Quarter + 1" refers to the forecast of the next fiscal quarter, and so on). Median analyst forecast revisions for the entire I/B/E/S database are trimmed 
at the 1 st and 99th percentiles. $* * *, * *$ and $*$ indicate significance of the OLS coefficients at the $1 \%, 5 \%$ and $10 \%$ levels, respectively.

\begin{tabular}{|c|c|c|c|c|c|c|}
\hline \multirow[b]{2}{*}{ Time period } & \multicolumn{2}{|c|}{ Intercept (alpha) } & \multicolumn{2}{|c|}{ RankSize } & \multicolumn{2}{|c|}{ UpwardEPS } \\
\hline & coeff & $\underline{\mathrm{t}-\mathrm{stat}}$ & $\underline{\text { coeff }}$ & $\underline{\mathrm{t} \text {-stat }}$ & $\underline{\text { coeff }}$ & $\underline{\text { t-stat }}$ \\
\hline Quarter + 0 & $-1.83 * * *$ & -21.37 & $0.31 * * *$ & 5.54 & $2.04 * * *$ & 15.50 \\
\hline Quarter + 1 & $-2.26 * * *$ & -18.59 & $0.58 * * *$ & 7.06 & $2.29 * * *$ & 11.99 \\
\hline Quarter + 2 & $-1.49 * * *$ & -14.47 & $0.40 * * *$ & 7.43 & $1.47 * * *$ & 9.15 \\
\hline Quarter + 3 & $-1.11 * * *$ & -11.86 & $0.31 * * *$ & 5.99 & $1.09 * * *$ & 7.18 \\
\hline Year +0 & $-6.71 * * *$ & -27.57 & $2.12 * * *$ & 13.65 & $6.91 * * *$ & 18.54 \\
\hline Year +1 & $-6.27 * * *$ & -22.35 & $1.66 * * *$ & 9.35 & $6.34 * * *$ & 14.00 \\
\hline Year +2 & $-6.01 * * *$ & -7.13 & $1.13 * * *$ & 2.77 & $6.47 * * *$ & 5.39 \\
\hline
\end{tabular}

Next, I use the estimated $\beta_{1}$ coefficients from equation (3) and each observation's RankSize to generate fitted values for each firm's expected forecast revisions $(E(F R))$ :

$$
E(F R)_{i, t}=\hat{\beta}_{1} \text { RankSize }_{i, t}+\phi .
$$

Each term in equation (4) addresses a key source of forecast bias: the $\hat{\beta}_{1}$ term addresses bias that is correlated with firm size, while $\phi$ (a number chosen to set mean AFR across a particular forecast measure and sample equal to zero) addresses forecast optimism bias that is common to all firms. My expected revisions thus vary based on firm size, but not a firm's past and future performance.

Table 2 presents mean AFRs following OMR announcements, mean AFRs for all other $\mathrm{I} / \mathrm{B} / \mathrm{E} / \mathrm{S}$ listed firms in all periods, and the difference in mean AFRs between these two groups. To see how my novel AFR measure produces different results than past studies, each panel computes AFR using a different definition of $E(F R)$. Panel A presents the results using $E(F R)=0$ (i.e. no bias adjustments, as in Jagannathan and Stephens (2003) and Peyer and Vermaelen (2009)), Panel B uses the definition of $E(F R)$ based on each firm's past and future average revisions (as in Grullon and Michaely (2004)), and Panel C sets $E(F R)$ equal to the result of equation (4) above.

At first glance, the negative repurchaser mean AFRs in Panel A suggest that unfavorable information is conveyed by OMR announcements. However, mean AFRs are 
also negative across all other I/B/E/S observations, and the mean differences between these two groups are generally insignificantly different from zero. With this additional context, it no longer appears that OMR announcements specifically convey negative information (on average) about earnings. These results also clearly illustrate the downward bias present in unadjusted forecast revisions. In Panel B, most mean AFR measures are significantly negative for the repurchasers (as expected, given the results in Grullon and Michaely (2004)) but not in the remaining I/B/E/S sample. It is yet unclear whether the negative average AFRs for repurchasers are the result of negative information about earnings or the effects of the historical performance-related bias discussed earlier. 
Table 2: Full Sample Univariate Tests of Abnormal Forecast Revisions

Caption: The variables of interest are the Abnormal Forecast Revisions for repurchasing firms from 1984-2011, where an Abnormal Forecast Revision is defined as the change in median forecasted earnings per share (scaled by lagged firm price) minus the "expected change" in the analyst earnings per share forecast. All abnormal forecast revisions are scaled up by 1,000. In Panel A, the "expected change" is equal to zero. In Panel $\mathrm{B}$, the expected change is defined as the average median revision in forecasted earnings-per-share for firm i (scaled by each firm's lagged price) for all time periods outside of the six months before and after the update period. In Panel $\mathrm{C}$, the expected change is equal to the result of equation (4) in this paper: $E(F R)_{i, t}=\hat{\beta}_{1} \operatorname{RankSize}_{i, t}+\phi\left(\right.$ where $\hat{\beta}_{1}$ was obtained from the regressions in equation (3) and $\phi$ is a number chosen to set the mean Abnormal Forecast Revisions equal to zero across a particular forecast measure and sample). All earnings-pershare forecast information is obtained from $\mathrm{I} / \mathrm{B} / \mathrm{E} / \mathrm{S}$. Median analyst forecasts for the entire $\mathrm{I} / \mathrm{B} / \mathrm{E} / \mathrm{S}$ database are trimmed at the 1st and 99th percentiles prior to the construction of the Abnormal Forecast Revision variable, and all observations with a lagged stock price of less than $\$ 1$ are dropped. "Time period" for the $\mathrm{I} / \mathrm{B} / \mathrm{E} / \mathrm{S}$ forecast measures is defined in Table 1. The first group of columns reports data on Abnormal Forecast Revisions following update periods when firms make open market repurchase announcements during the 19842011 sample period, the second group of columns reports data on Abnormal Forecast Revisions for all other I/B/E/S observations (when an open market repurchase is not announced) during the 1984-2011 sample period, and the third column reports the difference in means between these two groups. $* * *, * *$ and $*$ indicate significance using two-tailed t-tests at the $1 \%, 5 \%$ and $10 \%$ levels, respectively. 


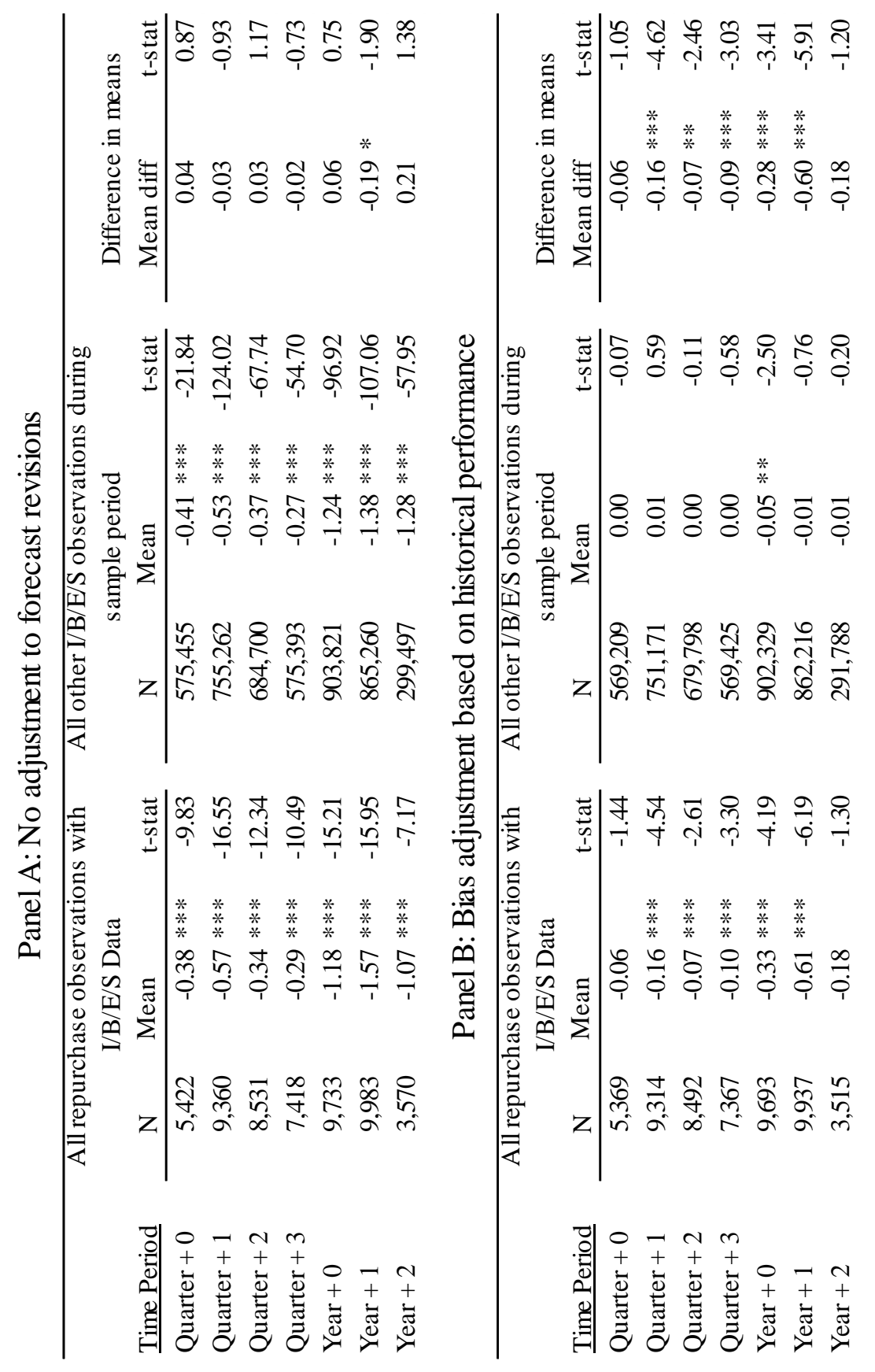




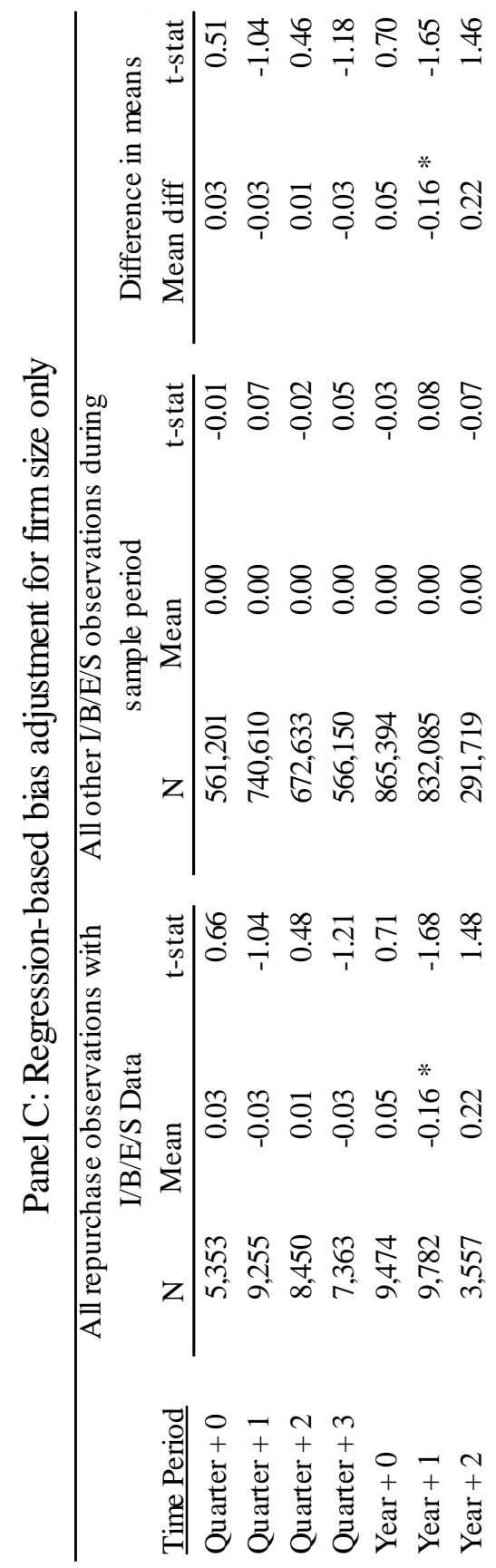


To help answer this question, Panel C presents results using the new AFR measure constructed in equations (2)-(4) above. The average revisions found in non-OMRannouncing firms in this panel are essentially zero (as expected, since equation (4) is designed to set sample-wide mean AFRs equal to zero). However, the revisions in OMRannouncing firms are also generally insignificantly different from zero. These results suggest that no positive or negative information about earnings is conveyed by the average announcement.

The AFR measures used in panels A through C illustrate how the use of different forecast revision measures can change perceptions of OMR announcements. Later tests will examine whether earnings information is found in certain, specific firms where repurchase motivations may be altered by an unanticipated legislative shock.

\section{III.B. Accounting and Economic Expectations Data}

I obtain quarterly accounting data from Compustat and match this data to the monthly I/B/E/S observations. I construct proxies for firm valuation (Average $Q$ ), dividend payments (DivPayer, equal to 1 if a firm paid a dividend in the prior quarter), firm size (LnAssets), profitability levels (Return on Cash-Adjusted Assets, or ROCAA), profitability trends (the quarter-over-quarter change in ROCAA, or ROCAA change), cash holdings (Cash/Assets), capital structure (DebtRatio), capital expenditures (ScaledCapEx), and the portion of equity from retained earnings (RE/TE). These or similar variables have been used in past studies of payout policy. Since an Average Q of less than one has proxied for payout motivations in previous studies (Lang and Litzenberger (1989)), I use two valuation variables in multiple regression tests: a version of Average $Q$ where values of $\mathrm{Q}$ below one are set equal to one, and Average $Q<1$, an indicator variable equal to one when Average $\mathrm{Q}$ is below one. All non-indicator variables are winsorized at the $1^{\text {st }}$ and $99^{\text {th }}$ percentiles and typically lagged by one quarter in tests. More details on the construction of these variables (and all others used in this study) are found in the appendix.

ROCAA is also used as an alternative proxy for post-OMR earnings in later tests. The cash-adjusted denominator ensures that the decrease in cash from actual share repurchases does not mechanically generate an increase in this measure. Grullon and Michaely (2004) and Lie (2005) use similar proxies, and Grullon and Michaely (2004) 
discuss the merits of this proxy due to its insensitivity to changes in capital structure, depreciation, and extraordinary items.

Since earnings forecasts are affected by economic conditions, I also construct a variable that proxies for current economic expectations using the monthly Smoothed U.S. Recession Probability, available from the Federal Reserve Economic Data (ALFRED) website. ${ }^{9}$ Any missing observations in the ALFRED database are assumed to have the previous month's recession probability. I create an indicator variable named Decline, which is equal to one when the recession probability is $10 \%$ or greater, as a proxy for periods when there is a non-trivial chance that the economy will enter a period of decline. (The correlation of this measure with NBER "decline from economic peak" months is 0.90 over my sample period, so this measure proxies well for actual macroeconomic information.) Since this measure is released on a two-month lag, I lag all Smoothed U.S. Recession Probabilities by two months in the construction of Decline.

Table 3 provides the mean and median values of the quarterly accounting variables. The first two columns present key firm characteristics for the OMR-announcing observations and all firm-quarter observations in Compustat from 1984-2011 where an announcement did not occur. OMR-announcing firms tend to be larger than other firms, so their forecast revisions should have a relatively smaller amount of "size-related bias". However, OMR-announcing firms are also substantially more profitable (mean and median ROCAA), reinforcing the need for a forecast measure free of historical performancerelated bias.

${ }^{9}$ http://alfred.stlouisfed.org/series?seid=RECPROUSM156N. Additional details about this variable were obtained from Jeremy Piger’s website: http://pages.uoregon.edu/jpiger/us_recession_probs.htm. 


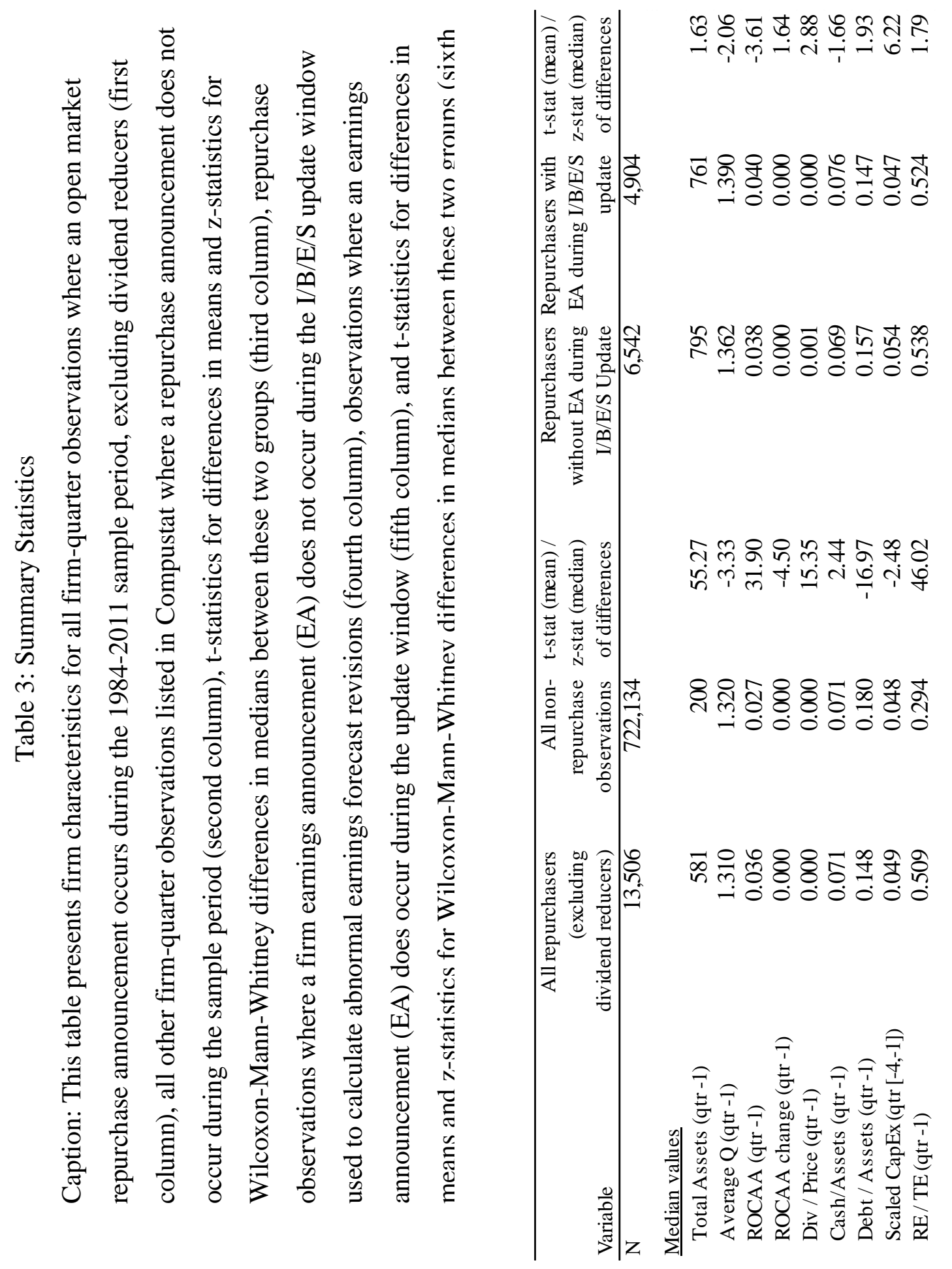


The fourth and fifth columns divide the repurchase observations with available I/B/E/S data into two categories: observations where a firm's quarterly earnings announcement (EA) does not occur during the same forecast update period as the repurchase announcement, and observations where an EA does occur during the update period. For subsequent tests of forecast revisions, I use only the observations that occur during forecast update periods without a contemporaneous earnings announcement. These observations make up more than half of my total sample with $\mathrm{I} / \mathrm{B} / \mathrm{E} / \mathrm{S}$ data, and the "with EA" and "without EA" groups appear more closely matched in terms of most firm characteristics.

I focus on this subsample for two reasons. First, when an earnings announcement occurs during the same forecast update period as a repurchase announcement, it is difficult to determine how much of the subsequent forecast revision to attribute to each event. For example, if some firms announce repurchase plans near relatively poor earnings releases, this might bias tests against finding evidence consistent with positive earnings information. (Consistent with this idea, in unreported tests I find that the mean and median changes in ROCAA are significantly negative in both the "with EA" and "without EA" subsamples.) Second, if any evidence of earnings information in OMR announcements exists, it should be easier to detect during the relatively less volatile periods when no new earnings information is released. ${ }^{10}$

\footnotetext{
${ }^{10}$ In unreported tests, I find that the sample variance for AFR is between 1.5 and 4.3 times higher for the "with EA" subsample than the "without EA" subsample (depending on the AFR timeframe used).
} 


\section{CHAPTER 4 - A LEGISLATIVE SHOCK TO REPURCHASE COSTS}

\section{IV.A. Description of the Shock}

Suppose an unanticipated shock were to generate higher costs associated with repurchases without affecting other factors that might influence earnings expectations (such as operating performance or investment choices). This shock would be exogenous, in the sense that it would affect earnings forecast revisions only through its effect on OMR announcements. Suppose further that outsiders believed that the firm would actually incur this cost after an OMR announcement by following through with actual repurchases. With both a cost and a commitment to the repurchase, earnings-based undervaluation explanations and signaling models would predict positive revisions in earnings expectations for these firms. If these explanations were not valid, we would expect no revisions (or even negative revisions, given the increased costs associated with the repurchases).

With this in mind, I propose that the May 2007 IRS regulation (Notice 2007-48) described in the introduction fits the structure of the shock described above. Prior to the passage of this regulation, many tax haven-using firms were believed to have repurchased shares in a way that circumvented paying taxes on the offshore-stored cash used for the repurchases. ${ }^{11}$ However, after the regulation's passage, U.S. firms funding repurchases using offshore, untaxed profits were required to repatriate and pay the taxes due on those profits. Alternatively, these repurchases could be funded by taking on debt or using

\footnotetext{
11 "I.B.M. used a foreign subsidiary to buy back shares through foreign exchanges. The subsidiary then used the shares to pay its corporate parent in America for goods and services...this technique was believed to be in wide use by corporations that have substantial profits offshore and are also buying back large amounts of their own shares to return value to investors." Johnston, David Cay, "I.R.S. Moves to Close Tax Shelter Shortly After I.B.M. Uses It to Save \$1.6 Billion”, The New York Times June 2007.
} 
domestically held cash, but this would be likely to constrain the repurchasers in other ways. For example, future profits that might otherwise have been transferred to offshore havens will instead go towards paying debt service or replenishing domestic cash reserves. ${ }^{12}$ There is no evidence that this regulation was anticipated by U.S. firms; by all accounts, the regulation's creation was prompted by an IBM repurchase announced just two days before Notice 2007-48 was released. ${ }^{13}$ This regulation creates an ideal setting for tests, since it should affect repurchasing firms in a heterogeneous fashion (as repurchase costs and decisions should only be altered in firms using tax havens).

Among all tax avoidance techniques, arguably the most effective is the "Double Irish with a Dutch sandwich" corporate subsidiary structure that allow U.S. corporations to significantly delay or reduce U.S. tax payments on corporate profits. To use these structures, firm managers set up an Irish subsidiary that will own the intellectual property (IP) for key company products. This subsidiary then licenses the IP to the corporate parent and a second Irish subsidiary. The firm sends profits from foreign sales to this first Irish subsidiary under the guise of "patent royalties", allowing the firm to avoid both foreign and U.S. taxes payable due to those sales. Although the first subsidiary is incorporated in Ireland, it is controlled or managed in a different tax haven country (such as Bermuda); under Irish law, if this subsidiary is managed from a headquarters office in a foreign country, it is considered a "dual resident" and these profits can be transferred to another subsidiary in a tax haven country without first being taxed in Ireland. A Dutch subsidiary is also used to avoid withholding taxes on transfers between the other subsidiaries. By using all of these subsidiaries in the prescribed way, tax payments end up much lower than under a direct transfer to a tax haven country. ${ }^{14}$ Figure 1 presents a more detailed overview of the specific steps needed to implement this structure.

\footnotetext{
${ }^{12}$ Large U.S. firms may keep as much as three-quarters of their cash abroad (Schoenberger, Cahan R., "What Are U.S. Companies Doing With Their Cash? Many Hold It Abroad", The Wall Street Journal July 2013); presumably these firms keep as little cash in the U.S. as they can without impeding their normal operations. ${ }^{13}$ Johnston, David Cay, "I.R.S. Moves to Close Tax Shelter Shortly After I.B.M. Uses It to Save \$1.6 Billion", The New York Times June 2007.

14 "Why would anyone opt for the Double Irish over the Single Bermudan? Because of tax treaties. When you transfer money within the EU, the government doesn't take a cut in the form of a withholding tax. When money goes directly to an unregulated country like Bermuda, however, it gets taxed at the origin country's normal rate." Lowder, J. Bryan, "The Double Irish and the Dutch Sandwich", Slate April 2011.
} 


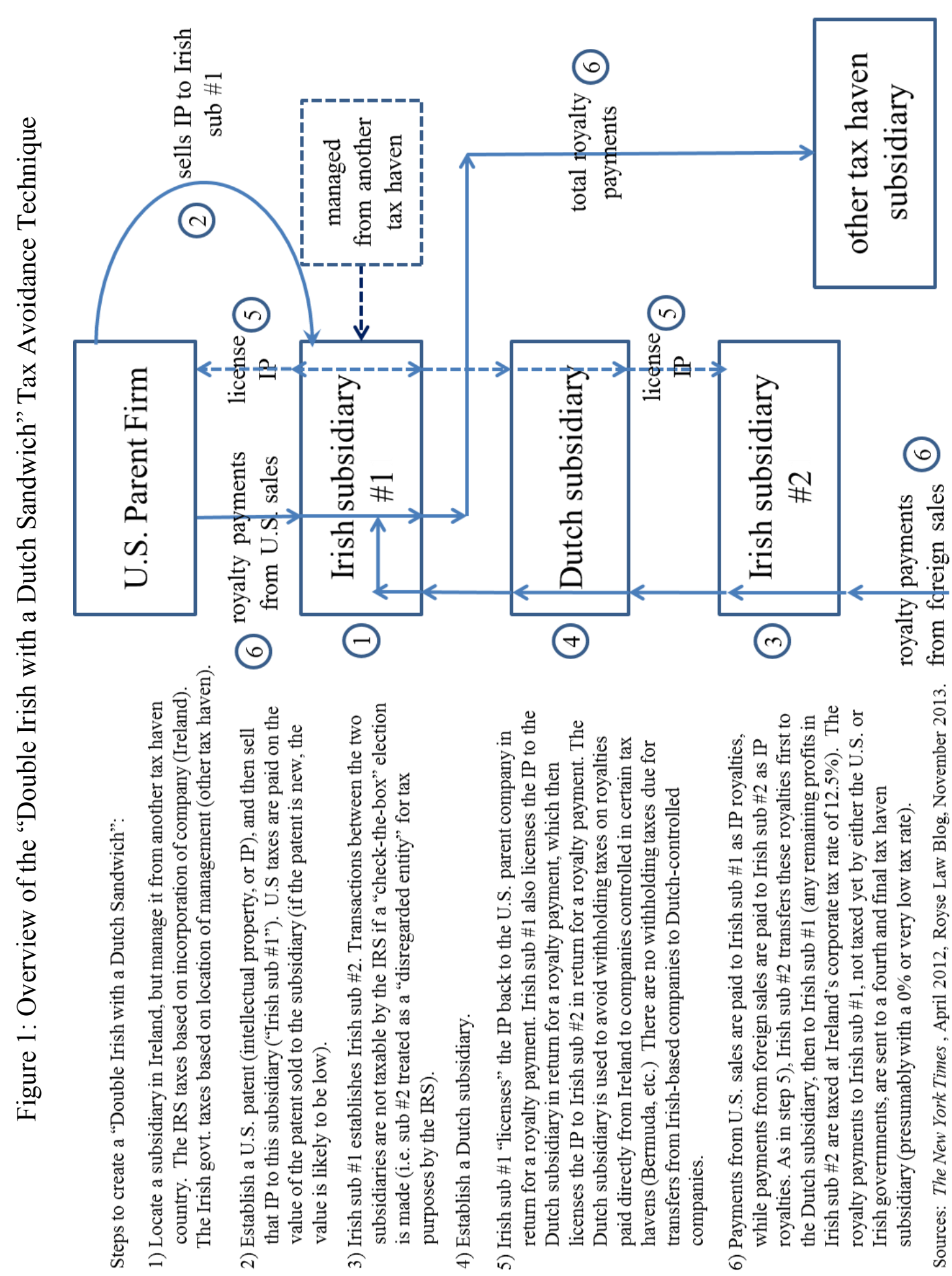


The earliest use of "Double Irish" structures I could find in the press dates back to Apple in the 1980s. ${ }^{15}$ As one might expect given the structure outlined above, firms with a great deal of proprietary intellectual property and foreign sales (such as firms in the pharmaceutical and technology industries) have most often been associated with "Double Irish" structures. Companies confirmed to have adopted this technique by press articles include Apple, Adobe Systems, Boston Scientific, eBay, Facebook, Amazon.com, Twitter, Microsoft, Intel, Novell, Yahoo, Abbott Laboratories, and Pfizer. The technique represents perhaps the most effective tax shelter structure to date. For example, Forest Laboratories cut its annual tax rate from $10.3 \%$ to $2.4 \%$ and Google reduced taxes by more than $\$ 3.1$ billion over three years using the technique. ${ }^{16}$

\section{IV.B. The Exogeneity of the Shock and Key Assumptions}

My tests using this shock rely on three assumptions: 1) the regulatory shock is exogenous and should have no direct impact on forecast revisions outside of its impact on repurchases, 2) repurchases by tax haven-using firms are more costly for these firms after the IRS regulation, and 3) outsiders interpret OMR announcements from "Double Irish" firms as credible commitments to repurchase. I lay out the evidence and logic behind these assumptions in the following paragraphs.

There are a number of reasons why the shock should not affect earnings expectations through other channels (besides the OMR announcement), as the first assumption suggests. Since the IRS regulation specifically affects corporate taxes, the regulation won't directly impact pre-tax operating performance. A more intuitive endogeneity concern is that the shock might have a direct effect on managers' investment decisions (and, in turn, earnings expectations) by altering the valuation of U.S. investment opportunities. However, both Dharmapala et al. (2011) and Faulkender and Petersen (2012) suggest that a recent shock to repatriation costs (the 2004 American Jobs Creation Act) had little effect on domestic investment in most U.S. firms. Finally, since repatriation

\footnotetext{
${ }^{15}$ Duhigg, Charles and David Kocieniewski, "How Apple Sidesteps Billions in Taxes", The New York Times April 2012.

${ }^{16}$ Drucker, Jesse, "U.S. Companies Dodge $\$ 60$ Billion in Taxes With Global Odyssey", Bloomberg News May 2010, "Google 2.4\% Rate Shows How \$60 Billion Lost to Tax Loopholes", Bloomberg News October 2010.
} 
is required only for domestic investments, the repurchase cost shock is not likely to directly affect foreign investment decisions in financially unconstrained firms.

Regarding the second assumption, many OMRs are funded with temporary spikes in non-operating earnings (Jagannathan, Stephens, and Weisbach (2000)) or excess cash. Since these funding methods are unlikely to result in reduced investment or new outside financing (the “costs" used in Miller and Rock's (1985) and Bhattacharya's (1979) signaling models, respectively), it is unclear whether the average OMR program is truly costly. However, there is anecdotal evidence that repurchasing firms with untaxed, offshore profits overseas did incur additional costs after the 2007 IRS ruling. Some firms chose to bring back offshore profits and pay repatriation taxes ${ }^{17}$ while others issued new debt or used domestic cash to fund share buybacks. ${ }^{18}$ Each of these choices carried an incremental cost of repurchasing, whether the cost was direct (repatriation taxes or interest payments on debt) or indirect (depletion of domestic cash reserves, which affects how much cash can be sent offshore in the future). In contrast to studies of repatriation related to domestic firm acquisitions (Martin et al. (2015)), I find no evidence that firms used "loopholes" to continue cost-free repatriation of foreign cash for repurchases after the 2007 regulation.

The third assumption relates to whether or not outsiders believe that managers will actually follow through on an announced OMR program. As Rau and Vermaelen (2002) and Lie (2005) note, managers are under no obligation to complete or even begin announced OMR programs. However, firms with tax havens typically have high cash holdings (Foley et al. (2007)) and are routinely scrutinized by shareholders due to these cash holdings, as the coverage of a recent Apple buyback illustrates. ${ }^{19}$ I assume that this combination of media attention and vocal shareholders makes these particular companies relatively more likely to actually follow through on announced OMR plans. Empirical

\footnotetext{
${ }^{17}$ These firms include eBay (Santoli, Michael, "Why is eBay eager to pay a tax that Apple works to avoid?", finance.yahoo.com, April 2014) and General Electric (McKinnon, John D. and Liz Hoffman, "GE Bites Tax Bullet in Move to Help Share Buybacks", The Wall Street Journal April 2015).

${ }^{18}$ Apple has done both in the past, using domestic cash reserves (Vascellaro, Jessica E., "Apple Pads Investor Wallets", The Wall Street Journal March 2012)) and issuing debt ("Apple's Tax Dodge”, cnn.com April 2013) to fund buybacks.

19 “Apple on Monday bowed to mounting pressure to return some of its roughly $\$ 100$ billion in cash reserves to shareholders...(shareholders) clamoring for a cut of Apple's growing cash stockpile increased in recent years..." Vascellaro, Jessica E., “Apple Pads Investor Wallets", The Wall Street Journal March 2012.
} 
evidence supports this claim; using actual repurchase data from Compustat (data item "cshopq"), I find that only $2.6 \%$ of firms likely to be using "Double Irish" structures fail to follow an OMR announcement with actual repurchases in the four quarters after the announcement (this fraction is more than four times higher for the remaining firms in my sample).

\section{IV.C. Data and Key Predictions}

To my knowledge, there is no complete, existing source for firms that have adopted Double Irish structures. I instead estimate which firms are more likely to use these structures. I begin by hand-collecting data on subsidiaries (and their country of incorporation) from Mergent for each NYSE, Nasdaq, and AMEX-listed firm in that database. This produces subsidiary information for 9,965 separate firms, which I handmatch to Compustat data based on company name. I classify a firm as likely to be using a "Double Irish with a Dutch Sandwich" structure (and set an indicator variable Irish Likely equal to one) if it has at least two subsidiaries incorporated in Ireland, one subsidiary incorporated in the Netherlands, and one subsidiary incorporated in another country commonly identified as a tax haven (using a list based on a Desai et al. (2006) study of tax havens). I further classify a firm as using any type tax haven (Any Haven $=1)$ if it contains at least one subsidiary incorporated in a country identified as a tax haven (based on the Desai et al. (2006) study). These countries include the Bahamas, Barbados, Bermuda, Cayman Islands, Hong Kong, Ireland, Liberia, Luxembourg, the Netherlands, Panama, Singapore, Switzerland, and the UK Virgin Islands. Irish Likely (Any Haven) firms make up $8.6 \%(36.0 \%)$ of total firm assets in the last eight years of my sample. ${ }^{20}$

\footnotetext{
${ }^{20}$ Since the Mergent data reflects only the most recent company filings, the haven identification indicators are time invariant. Therefore another key assumption in my tests is that these haven structures or similarly aggressive tax avoidance structures were in place at the time of or shortly after the IRS regulation.
} 


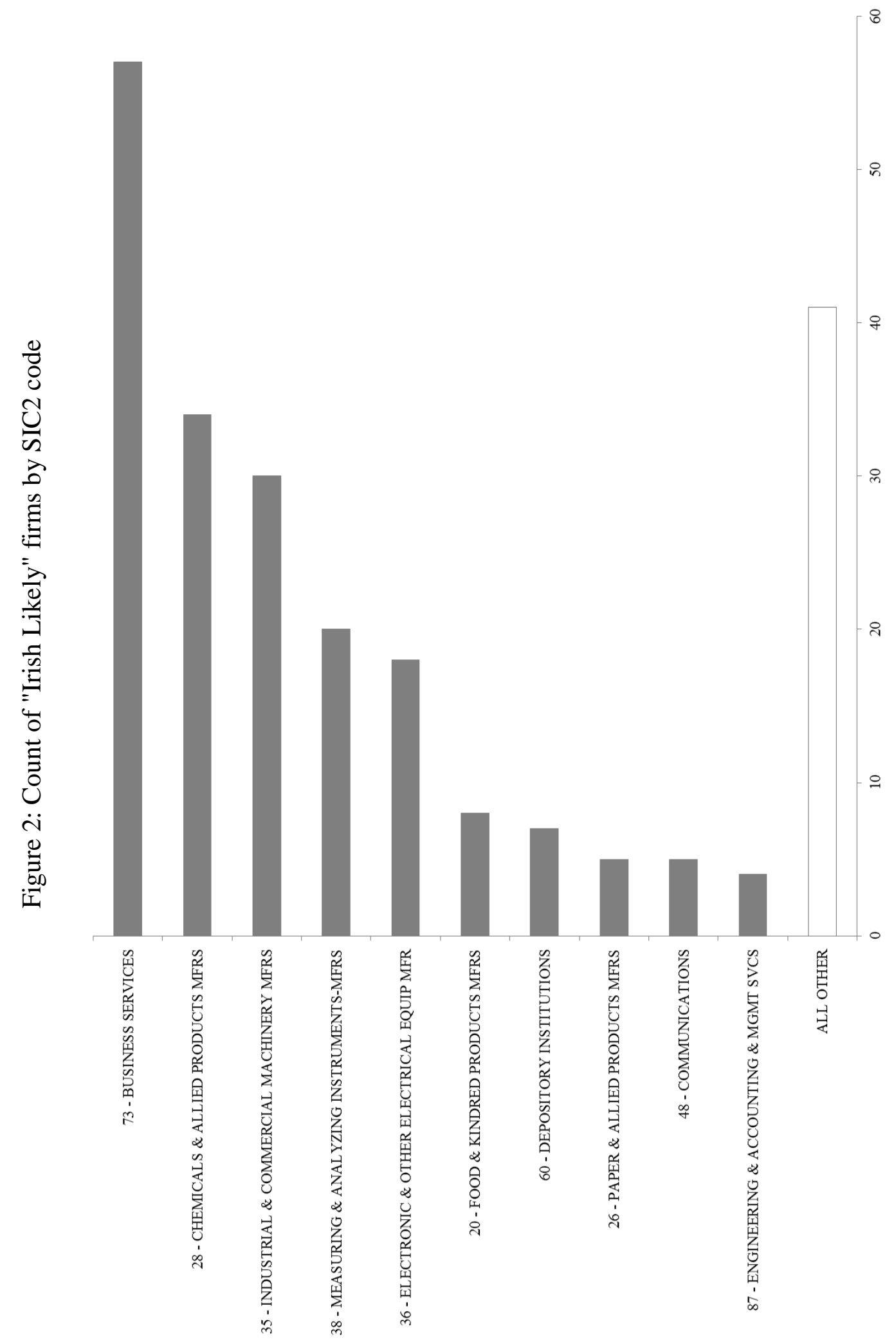


Although many firms establish subsidiaries in foreign countries due to business interests in those countries, the unique structure of the "Double Irish" method makes it highly likely that firms with this combination of subsidiaries are using this tax avoidance technique. However, the possibility remains that my procedure could misclassify firms as "Irish Likely" if they use the subsidiaries described above for some purpose other than tax avoidance (or I could misclassify firms as "non-Irish Likely" if they fail to disclose key subsidiary information, despite the SEC requirement to do so). To examine whether this classification process appears to accurately identify "Irish Likely" firms, in Figure 2 I present an SIC 2-digit industry-level breakdown of all Compustat-listed firms where Irish Likely is equal to 1 . As expected, these firms are concentrated in industries where Double Irish structures have been identified in the popular press, such as business services (Adobe, eBay, Facebook, Google, Microsoft), chemicals \& allied products (Abbott Laboratories, Forest Laboratories, Pfizer), industrial and commercial machinery (Apple), measuring and analyzing instruments (Boston Scientific), and electronic and other electrical equipment (Intel).

These variables, along with an indicator variable (After Law) signifying the period after the passage of the IRS regulation, allow me to use the regulation as a quasi-natural experiment to test three predictions using the proxy for revisions in earnings expectations (AFR). The first prediction follows directly from the signaling and earnings-related undervaluation hypotheses:

1. AFR should be positive, on average, after the IRS regulation in the OMRannouncing firms more likely to be storing untaxed profits in offshore tax havens.

After the regulation, tax-avoiding firms have a choice: repurchase shares and bear the incremental cost, or don't repurchase and avoid this cost. For non-tax-avoiding firms with sufficient cash to fund an OMR program, their repurchase decisions are not accompanied by the same types of incremental costs, either before or after the reform. Put differently, the 2007 regulation should alter repurchase-related decision making only in firms taking advantage of foreign tax havens. This leads to my second prediction: 
2. The change in repurchaser AFR from before to after the regulation should be higher for firms likely to be utilizing tax havens than other firms (a "difference-indifference" test).

Finally, one key empirical challenge of payout policy studies is that the same accounting and economic variables that typically proxy for repurchase motivations may also directly influence AFRs in all firms. For example, Average Q may proxy for repurchase motives related to overinvestment concerns, but $\mathrm{Q}$ is also plausibly related to earnings expectations for all firms (as firms with low Q might be more likely to have negative AFRs). To argue that positive AFRs are consistent with positive earnings information conveyed by OMR announcements, a falsification test is necessary to demonstrate that evidence of positive mean AFRs is only found in periods when an OMR program is announced. This leads to the third and final prediction:

3. The "difference-in-difference" from Prediction 2 should be positive and significant for OMR-announcement periods but not for other periods (a "triple difference" test).

Evidence consistent with these predictions should be the strongest in the "Double Irish"likely firm subsample, since repurchases should be relatively more costly on average for firms using the (more effective) Double Irish structure than the larger subsample of firms using any tax haven.

Although it is possible that any better-than-expected earnings signaled by OMR announcements would not be detectable if they are offset by additional repurchase costs, this is unlikely to be the case for two reasons. First, firms are unlikely to repurchase due to better-than-expected earnings if the benefits of repurchasing are completely offset by additional tax costs. Second, numerous studies have shown that analysts fail to fully incorporate known changes in tax impacts into their forecasts (Chen and Schoderbek (2000), Plumlee (2003), Kim, Schmidt, and Wentland (2014)), perhaps because the costs of incorporating this complex information exceed the benefits to these analysts (Plumlee (2003)). Later tests of actual earnings use a pre-tax measure of earnings (ROCAA) that should be unaffected by any tax-related costs. 
My empirical methodology is designed to minimize the possibility that events or factors other than the IRS regulation could explain my test results. First, I use a variety of fixed effects in my multiple regression tests. For example, I include month-year fixed effects in several specifications. For some omitted variable or event (contemporaneous with the passage of the regulation) to be able to explain my results in these specifications, this variable would need to positively correlate with the indicator variable for "Double Irish" firms and have a similar predicted effect on forecast revisions. I also use firm fixed effects to conduct within-firm tests of whether analyst reactions to OMR announcements change after the passage of the 2007 regulation. Second, I include non-repurchaseannouncing firms in my triple difference specifications as a falsification test. Any omitted variable responsible for the results would not only need to correlate with the "Double Irish" and tax haven indicators, it would also have to have a much stronger positive correlation specifically in repurchase-announcing "Double Irish"/tax haven firms. 


\section{CHAPTER 5 - TESTS AND RESULTS USING THE LEGISLATIVE SHOCK}

\section{V.A Main Tests of Abnormal Forecast Revisions}

In this section, I test my predictions in a variety of empirical settings. My tests use two different sample periods: a subset of years directly surrounding the IRS regulation (2004-2011) and the full sample used in earlier tests (1984-2011). Table 4 presents the results of univariate tests of AFRs using subsamples based on the Irish Likely and After Law indicators.

Panel A presents mean AFRs following forecast update periods when OMRs are announced, while Panel B uses all remaining observations. For the firms where repurchases are likely to be costly ("Irish Likely" firms after the IRS law, shown in the middle box in Panel A), the mean AFRs are positive for every timeframe and typically statistically significant, consistent with my first prediction. Notably, these positive AFRs are found despite the post-law period coinciding with the global financial crisis of 2008-2009, which should negatively impact AFR in most firms (this is confirmed by the coefficient and significance of Decline in later multivariate tests). The results are also consistent with my second prediction, as the differences in mean AFRs from before to after the regulation are significantly higher in "Irish Likely" firms than other firms in most cases (as shown in the "difference-in-difference" results in the lower right corner).

The results are noticeably different for non-OMR-announcement periods. In Panel B, there is no evidence that the "Irish Likely", post-law-change firms have significantly positive AFRs (on average) during these periods. There is also no evidence that "Irish Likely" firms show greater average AFR increases than non-"Irish Likely" firms after the IRS law. The bottom-right box in Panel B computes the "triple difference" measures outlined in my third prediction, which are positive in all cases and statistically significant 
in six of seven cases. Panels C and D repeat these tests in the 1984-2011 sample with similar conclusions.

Table 4: Univariate Difference-in-Difference Tests Using a Shock to Repurchase Costs Caption: The variables of interest are Abnormal Forecast Revisions (AFRs) for firms, where an Abnormal Forecast Revision is defined as the change in median forecasted earnings-per-share (scaled by lagged firm price) minus the "expected change" in the analyst earnings-per-share forecast. The "expected change" used in the AFR calculation is the same measure used in Table 2, Panel C. Only observations where the forecast revision does not contain a contemporaneous earnings announcement are included. AFR measures are scaled up by 1,000. All earning-per-share forecast information is obtained from I/B/E/S. Median analyst forecasts for the entire $\mathrm{I} / \mathrm{B} / \mathrm{E} / \mathrm{S}$ database are trimmed at the 1st and 99th percentiles prior to the construction of AFR, and all observations with a lagged stock price of less than $\$ 1$ are dropped. "Time period" for the $\mathrm{I} / \mathrm{B} / \mathrm{E} / \mathrm{S}$ forecast measures is defined in Table 1. After Law is equal to one if the the observation is between June 2007 and the end of 2011 (and zero otherwise). Irish Likely is equal to one if a firm has at least two subsidiaries incorporated in Ireland, one subsidiary incorporated in the Netherlands, and one subsidiary incorporated in another tax haven country, as classified by Desai et al. (2006) (and zero otherwise). Panels A and C use AFRs following update periods when firms make open market repurchase announcements, and Panels B and D use AFRs for all other $\mathrm{I} / \mathrm{B} / \mathrm{E} / \mathrm{S}$ observations. $* * *, * *$ and $*$ indicate significance using two-tailed t-tests at the $1 \%, 5 \%$ and $10 \%$ levels, respectively. 
Panel A: Sample from 2004-2011, Repurchase-Announcing Firm Observations

\begin{tabular}{|c|c|c|c|c|c|c|c|c|c|c|}
\hline \multicolumn{4}{|c|}{ After Law $=0$, Irish Likely $=0$} & \multicolumn{4}{|c|}{ After Law $=0$, Irish Likely $=1$} & \multicolumn{3}{|c|}{ difference $($ Irish Likely $=1-$ Irish Likely $=0)$} \\
\hline Time Pd & $\underline{N}$ & $\underline{\text { Mean }}$ & $\underline{\text { tstat }}$ & Time Pd & $\underline{\mathrm{N}}$ & $\underline{\text { Mean }}$ & tstat & Time Pd & $\underline{\text { Mean }}$ & $\underline{\text { tstat }}$ \\
\hline $\mathrm{Qtr}+0$ & 570 & -0.07 & -1.01 & Qtr + 0 & 73 & 0.12 & 1.22 & Qtr +0 & 0.19 & 1.58 \\
\hline Qtr + 1 & 581 & $0.09 *$ & 1.87 & Qtr + 1 & 73 & -0.04 & -0.28 & Qtr + 1 & -0.13 & -0.85 \\
\hline $\mathrm{Qtr}+2$ & 569 & $0.13 * * *$ & 2.65 & $\mathrm{Qtr}+2$ & 73 & 0.03 & 0.24 & $\mathrm{Qtr}+2$ & -0.10 & -0.75 \\
\hline $\mathrm{Qtr}+3$ & 537 & 0.08 & 1.55 & Qtr + 3 & 71 & 0.02 & 0.20 & $\mathrm{Qtr}+3$ & -0.05 & -0.42 \\
\hline Year +0 & 596 & 0.15 & 1.12 & Year +0 & 73 & 0.10 & 0.43 & Year +0 & -0.05 & -0.18 \\
\hline Year + 1 & 587 & $0.51 * *$ & 2.06 & Year +1 & 72 & 0.47 & 0.96 & Year +1 & -0.04 & -0.07 \\
\hline Year +2 & 360 & $0.80 * * *$ & 4.83 & Year +2 & 66 & 0.27 & 0.48 & Year +2 & -0.53 & -0.90 \\
\hline \multicolumn{4}{|c|}{ After Law $=1$, Irish Likely $=0$} & \multicolumn{4}{|c|}{ After Law $=1$, Irish Likely $=1$} & \multicolumn{3}{|c|}{ difference (Irish Likely $=1-$ Irish Likely $=0$ ) } \\
\hline Time Pd & $\underline{N}$ & Mean & $\underline{\text { tstat }}$ & Time $\mathrm{Pd}$ & $\underline{N}$ & Mean & $\underline{\text { tstat }}$ & $\underline{\text { Time } \mathrm{Pd}}$ & Mean & $\underline{\text { tstat }}$ \\
\hline $\mathrm{Qtr}+0$ & 875 & 0.06 & 0.89 & Qtr + 0 & 87 & $0.23 * * *$ & 5.81 & $\mathrm{Qtr}+0$ & $0.17 * *$ & 2.07 \\
\hline $\mathrm{Qtr}+1$ & 847 & $-0.22 * *$ & -1.98 & Qtr + 1 & 80 & $0.12 * * *$ & 3.59 & Qtr + 1 & $0.34 * * *$ & 2.92 \\
\hline $\mathrm{Qtr}+2$ & 747 & $-0.20 * *$ & -2.13 & $\mathrm{Qtr}+2$ & 73 & $0.20 * * *$ & 4.13 & $\mathrm{Qtr}+2$ & $0.40 * * *$ & 3.82 \\
\hline $\mathrm{Qtr}+3$ & 677 & $-0.16 *$ & -1.67 & Qtr + 3 & 70 & $0.15 * * *$ & 2.65 & $\mathrm{Qtr}+3$ & $0.32 * * *$ & 2.79 \\
\hline Year +0 & 876 & -0.44 & -1.63 & Year +0 & 79 & 0.14 & 0.73 & Year +0 & $0.58 *$ & 1.74 \\
\hline Year + 1 & 664 & $-0.81 * *$ & -2.14 & Year +1 & 60 & $0.56 * * *$ & 5.92 & Year +1 & $1.38 * * *$ & 3.52 \\
\hline Year +2 & 331 & $-1.30 * *$ & -2.18 & Year +2 & 38 & $1.00 * *$ & 2.20 & Year +2 & $2.31 * * *$ & 3.07 \\
\hline \multicolumn{4}{|c|}{ difference (After Law $=1-$ After Law $=0)$} & \multicolumn{4}{|c|}{ difference (After Law $=1-$ After Law $=0)$} & \multicolumn{3}{|c|}{ difference-in-difference } \\
\hline$\underline{\text { Time } \mathrm{Pd}}$ & & $\underline{\text { Mean }}$ & $\underline{\text { tstat }}$ & $\underline{\text { Time } P d}$ & & $\underline{\text { Mean }}$ & $\underline{\text { tstat }}$ & $\underline{\text { Time } P d}$ & $\underline{\text { Mean }}$ & $\underline{\text { tstat }}$ \\
\hline Qtr + 0 & & 0.13 & 1.34 & Qtr + 0 & & 0.11 & 1.08 & Qtr + 0 & -0.02 & -0.15 \\
\hline Qtr + 1 & & $-0.31 * * *$ & -2.57 & Qtr + 1 & & 0.16 & 1.05 & Qtr + 1 & $0.48 * *$ & 2.42 \\
\hline $\mathrm{Qtr}+2$ & & $-0.32 * * *$ & -3.12 & Qtr + 2 & & 0.17 & 1.32 & Qtr + 2 & $0.50 * * *$ & 2.97 \\
\hline Qtr + 3 & & $-0.24 * *$ & -2.20 & Qtr + 3 & & 0.13 & 0.98 & Qtr + 3 & $0.37 * *$ & 2.16 \\
\hline Year +0 & & $-0.59 *$ & -1.96 & Year +0 & & 0.04 & 0.14 & Year +0 & 0.63 & 1.46 \\
\hline Year + 1 & & $-1.32 * * *$ & -2.92 & Year +1 & & 0.09 & 0.19 & Year +1 & $1.42 * *$ & 2.10 \\
\hline Year +2 & & $-2.10 * * *$ & -3.39 & Year +2 & & 0.73 & 1.01 & Year +2 & $2.83 * * *$ & 2.98 \\
\hline
\end{tabular}


Panel B: Sample from 2004-2011, All Other Firm Observations

\begin{tabular}{|c|c|c|c|c|c|c|c|c|c|c|}
\hline \multicolumn{4}{|c|}{ After Law $=0$, Irish Likely $=0$} & \multicolumn{4}{|c|}{ After Law $=0$, Irish Likely $=1$} & \multicolumn{3}{|c|}{ difference (Irish Likely $=1$ - Irish Likely $=0)$} \\
\hline Time Pd & $\underline{\mathrm{N}}$ & Mean & tstat & Time Pd & $\underline{\mathrm{N}}$ & Mean & $\underline{\text { tstat }}$ & Time Pd & Mean & tstat \\
\hline$\overline{\mathrm{Qtr}+0}$ & $63,6 \overline{60}$ & $0.07 * * *$ & $\overline{6.83}$ & $\overline{\mathrm{Qtr}+0}$ & $3,3 \overline{64}$ & $0.20 * * *$ & $\overline{13.35}$ & $\overline{\mathrm{Qtr}+0}$ & $0.13 * * *$ & 7.10 \\
\hline Qtr + 1 & 71,985 & $0.13 * * *$ & 14.27 & Qtr + 1 & 3,926 & $0.16 * * *$ & 14.49 & Qtr + 1 & 0.02 & 1.49 \\
\hline $\mathrm{Qtr}+2$ & 68,493 & $0.15 * * *$ & 17.23 & $\mathrm{Qtr}+2$ & 3,851 & $0.17 * * *$ & 15.36 & $\mathrm{Qtr}+2$ & $0.03 *$ & 1.92 \\
\hline Qtr + 3 & 54,223 & $0.11 * * *$ & 14.29 & Qtr + 3 & 3,208 & $0.13 * * *$ & 10.05 & $\mathrm{Qtr}+3$ & 0.02 & 1.33 \\
\hline Year +0 & 79,681 & $0.25 * * *$ & 10.32 & Year +0 & 3,951 & $0.27 * * *$ & 10.87 & Year +0 & 0.01 & 0.36 \\
\hline Year +1 & 77,297 & $0.49 * * *$ & 17.76 & Year +1 & 3,949 & $0.62 * * *$ & 17.42 & Year +1 & $0.13 * * *$ & 2.98 \\
\hline Year +2 & 38,334 & $0.59 * * *$ & 11.26 & Year +2 & 2,892 & $0.67 * * *$ & 11.33 & Year +2 & 0.07 & 0.94 \\
\hline \multicolumn{4}{|c|}{ After Law $=1$, Irish Likely $=0$} & \multicolumn{4}{|c|}{ After Law $=1$, Irish Likely $=1$} & \multicolumn{3}{|c|}{ difference (Irish Likely $=1-$ Irish Likely $=0$ ) } \\
\hline Time Pd & $\underline{\mathrm{N}}$ & Mean & $\underline{\text { tstat }}$ & Time Pd & $\underline{\mathrm{N}}$ & Mean & $\underline{\text { tstat }}$ & Time Pd & Mean & $\underline{\text { tstat }}$ \\
\hline$\overline{\mathrm{Qtr}+0}$ & $94,5 \overline{67}$ & $\overline{-0.05} * * *$ & $\overline{-3.29}$ & $\overline{\mathrm{Qtr}+0}$ & $4,4 \overline{87}$ & $\overline{-0.01}$ & $\overline{-0.24}$ & $\overline{\mathrm{Qtr}+0}$ & $\overline{0.05}$ & 1.37 \\
\hline $\mathrm{Qtr}+1$ & 101,182 & $-0.10 * * *$ & -3.43 & $\mathrm{Qtr}+1$ & 4,836 & $-0.06 * *$ & -2.00 & $\mathrm{Qtr}+1$ & 0.04 & 1.01 \\
\hline $\mathrm{Qtr}+2$ & 93,272 & $-0.11 * * *$ & -3.24 & $\mathrm{Qtr}+2$ & 4,566 & -0.02 & -0.84 & $\mathrm{Qtr}+2$ & $0.09 * *$ & 2.08 \\
\hline $\mathrm{Qtr}+3$ & 73,862 & $-0.09 * * *$ & -4.89 & $\mathrm{Qtr}+3$ & 3,827 & 0.01 & 0.32 & $\mathrm{Qtr}+3$ & $0.10 * * *$ & 2.72 \\
\hline Year + 0 & 110,252 & $-0.18 * * *$ & -4.58 & Year +0 & 4,969 & $-0.27 * * *$ & -3.40 & Year +0 & -0.09 & -1.00 \\
\hline Year + 1 & 87,362 & $-0.45 * * *$ & -4.67 & Year +1 & 4,016 & $-0.19 * *$ & -2.07 & Year +1 & $0.25 *$ & 1.90 \\
\hline Year + 2 & 38,903 & $-0.61 * * *$ & -5.12 & Year +2 & 2,492 & $-0.35 * *$ & -2.35 & Year +2 & 0.25 & 1.33 \\
\hline \multicolumn{4}{|c|}{ difference (After Law $=1-$ After Law $=0)$} & \multicolumn{4}{|c|}{ difference (After Law $=1-$ After Law $=0$ ) } & \multicolumn{3}{|c|}{ difference-in-difference } \\
\hline Time Pd & & Mean & $\underline{\text { tstat }}$ & $\underline{\text { Time } P d}$ & & $\underline{\text { Mean }}$ & $\underline{\text { tstat }}$ & Time Pd & Mean & $\underline{\text { tstat }}$ \\
\hline $\mathrm{Qtr}+0$ & & $-0.12 * * *$ & -6.41 & Qtr +0 & & $-0.20 * * *$ & -6.10 & Qtr +0 & $-0.08 * *$ & -2.08 \\
\hline $\mathrm{Qtr}+1$ & & $-0.23 * * *$ & -7.74 & Qtr +1 & & $-0.21 * * *$ & -6.98 & Qtr +1 & 0.02 & 0.46 \\
\hline $\mathrm{Qtr}+2$ & & $-0.26 * * *$ & -7.22 & Qtr +2 & & $-0.19 * * *$ & -6.84 & Qtr +2 & 0.06 & 1.39 \\
\hline Qtr +3 & & $-0.20 * * *$ & -10.19 & Qtr +3 & & $-0.12 * * *$ & -3.63 & Qtr +3 & $0.08 * *$ & 1.98 \\
\hline Year +0 & & $-0.43 * * *$ & -9.38 & Year +0 & & $-0.53 * * *$ & -6.49 & Year +0 & -0.10 & -1.06 \\
\hline Year + 1 & & $-0.93 * * *$ & -9.38 & Year +1 & & $-0.81 * * *$ & -8.12 & Year +1 & 0.12 & 0.85 \\
\hline \multirow[t]{10}{*}{ Year +2} & & $-1.20 * * *$ & -9.24 & Year +2 & & $-1.02 * * *$ & -6.32 & Year +2 & 0.18 & 0.87 \\
\hline & & & & & & & & \multicolumn{3}{|c|}{$\begin{array}{l}\text { triple difference (repurchaser vs. all other } \\
\text { firms, 2004-2011) }\end{array}$} \\
\hline & & & & & & & & & Mean & $\underline{\text { tstat }}$ \\
\hline & & & & & & & & Qtr + 0 & 0.06 & 0.40 \\
\hline & & & & & & & & Qtr + 1 & $0.46 * *$ & 2.26 \\
\hline & & & & & & & & $\mathrm{Qtr}+2$ & $\mathbf{0 . 4 3} * *$ & 2.50 \\
\hline & & & & & & & & Qtr +3 & $0.30 *$ & 1.68 \\
\hline & & & & & & & & Year +0 & $0.73 *$ & 1.66 \\
\hline & & & & & & & & Year +1 & $1.30 *$ & 1.88 \\
\hline & & & & & & & & ear +2 & $2.65 * * *$ & 2.72 \\
\hline
\end{tabular}


Panel C: Sample from 1984-2011, Repurchase-Announcing Firm Observations

\begin{tabular}{|c|c|c|c|c|c|c|c|c|c|c|}
\hline \multicolumn{4}{|c|}{ After Law $=0$, Irish Likely $=0$} & \multicolumn{4}{|c|}{ After Law $=0$, Irish Likely $=1$} & \multicolumn{3}{|c|}{ difference $($ Irish Likely $=1-$ Irish Likely $=0)$} \\
\hline Time Pd & $\underline{N}$ & Mean & $\underline{\text { tstat }}$ & Time Pd & $\underline{N}$ & Mean & $\underline{\text { tstat }}$ & Time Pd & $\underline{\text { Mean }}$ & $\underline{\text { tstat }}$ \\
\hline Qtr + 0 & 3,567 & -0.07 & -1.39 & Qtr +0 & 305 & $0.20 * * *$ & 4.97 & Qtr + 0 & $0.27 * * *$ & 4.31 \\
\hline Qtr + 1 & 3,301 & -0.02 & -0.52 & Qtr + 1 & 303 & 0.01 & 0.25 & Qtr + 1 & 0.04 & 0.52 \\
\hline $\mathrm{Qtr}+2$ & 2,996 & 0.03 & 0.77 & Qtr + 2 & 296 & 0.06 & 1.22 & Qtr + 2 & 0.03 & 0.57 \\
\hline $\mathrm{Qtr}+3$ & 2,489 & -0.01 & -0.15 & Qtr + 3 & 267 & 0.02 & 0.29 & $\mathrm{Qtr}+3$ & 0.02 & 0.33 \\
\hline Year +0 & 4,296 & -0.03 & -0.29 & Year +0 & 317 & $0.45 * * *$ & 4.18 & Year +0 & $0.48 * * *$ & 3.19 \\
\hline Year +1 & 3,886 & $-0.23 *$ & -1.68 & Year +1 & 310 & $0.50 * * *$ & 3.21 & Year +1 & $0.72 * * *$ & 3.53 \\
\hline Year +2 & 1,087 & 0.16 & 1.23 & Year +2 & 186 & 0.36 & 1.18 & Year +2 & 0.20 & 0.60 \\
\hline \multicolumn{4}{|c|}{ After Law $=1$, Irish Likely $=0$} & \multicolumn{4}{|c|}{ After Law $=1$, Irish Likely $=1$} & \multicolumn{3}{|c|}{ difference (Irish Likely $=1-$ Irish Likely $=0)$} \\
\hline Time Pd & $\underline{N}$ & Mean & $\underline{\text { tstat }}$ & Time Pd & $\underline{N}$ & Mean & $\underline{\text { tstat }}$ & Time Pd & $\underline{\text { Mean }}$ & $\underline{\text { tstat }}$ \\
\hline Qtr + 0 & 875 & $0.21 * * *$ & 2.97 & $\mathrm{Qtr}+0$ & 87 & $0.37 * * *$ & 9.52 & $\mathrm{Qtr}+0$ & $0.17 * *$ & 2.07 \\
\hline $\mathrm{Qtr}+1$ & 847 & $-0.18 *$ & -1.65 & Qtr + 1 & 80 & $0.16 * * *$ & 4.72 & Qtr + 1 & $0.34 * * *$ & 2.92 \\
\hline $\mathrm{Qtr}+2$ & 747 & $-0.21 * *$ & -2.24 & $\mathrm{Qtr}+2$ & 73 & $0.19 * * *$ & 3.92 & $\mathrm{Qtr}+2$ & $0.40 * * *$ & 3.82 \\
\hline $\mathrm{Qtr}+3$ & 677 & $-0.17 *$ & -1.70 & $\mathrm{Qtr}+3$ & 70 & $0.15 * * *$ & 2.60 & Qtr + 3 & $0.32 * * *$ & 2.79 \\
\hline Year +0 & 876 & 0.04 & 0.14 & Year +0 & 79 & $0.62 * * *$ & 3.13 & Year +0 & $0.58 *$ & 1.74 \\
\hline Year + 1 & 664 & $-0.65 *$ & -1.71 & Year +1 & 60 & $0.73 * * *$ & 7.66 & Year + 1 & $1.38 * * *$ & 3.52 \\
\hline Year +2 & 331 & $-1.37 * *$ & -2.29 & Year +2 & 38 & $0.94 * *$ & 2.06 & Year +2 & $2.31 * * *$ & 3.07 \\
\hline \multicolumn{4}{|c|}{ difference (After Law $=1-$ After Law $=0)$} & \multicolumn{4}{|c|}{ difference (After Law $=1-$ After Law $=0)$} & \multicolumn{3}{|c|}{ difference-in-difference } \\
\hline Time Pd & & Mean & $\underline{\text { tstat }}$ & Time Pd & & Mean & tstat & Time Pd & Mean & tstat \\
\hline Qtr + 0 & & $0.27 * * *$ & 3.24 & Qtr +0 & & $0.17 * * *$ & 3.01 & Qtr + 0 & -0.10 & -1.01 \\
\hline Qtr + 1 & & -0.16 & -1.34 & Qtr + 1 & & $0.14 * *$ & 2.20 & Qtr + 1 & $0.30 * *$ & 2.23 \\
\hline Qtr + 2 & & $-0.23 * *$ & -2.37 & Qtr + 2 & & $0.13 *$ & 1.88 & Qtr + 2 & $0.36 * * *$ & 3.02 \\
\hline $\mathrm{Qtr}+3$ & & -0.16 & -1.53 & Qtr + 3 & & 0.13 & 1.55 & Qtr + 3 & $0.29 * *$ & 2.17 \\
\hline Year +0 & & 0.07 & 0.24 & Year +0 & & 0.17 & 0.75 & Year +0 & 0.10 & 0.28 \\
\hline Year + 1 & & -0.42 & -1.05 & Year +1 & & 0.23 & 1.29 & Year + 1 & 0.66 & 1.49 \\
\hline Year +2 & & $-1.53 * *$ & -2.50 & Year +2 & & 0.58 & 1.06 & Year + 2 & $2.11 * * *$ & 2.57 \\
\hline
\end{tabular}


Panel D: Sample from 1984-2011, All Other Firm Observations

\begin{tabular}{|c|c|c|c|c|c|c|c|c|c|c|}
\hline \multicolumn{4}{|c|}{ After Law $=0$, Irish Likely $=0$} & \multicolumn{4}{|c|}{ After Law $=0$, Irish Likely $=1$} & \multicolumn{3}{|c|}{ difference (Irish Likely $=1-$ Irish Likely $=0)$} \\
\hline Time Pd & $\underline{\underline{N}}$ & Mean & tstat & Time Pd & $\underline{\underline{N}}$ & Mean & tstat & Time Pd & Mean & tstat \\
\hline$\overline{\mathrm{Qtr}+0}$ & $313,18 \overline{5}$ & $\overline{-0.04} * * *$ & $\overline{-5.77}$ & $\overline{\mathrm{Qtr}+0}$ & $16,19 \overline{5}$ & $\overline{0.23} * * *$ & $\overline{23.16}$ & $\overline{\mathrm{Qtr}+0}$ & $0.27 * * *$ & 22.14 \\
\hline $\mathrm{Qtr}+1$ & 321,573 & $0.01 * *$ & 2.23 & Qtr + 1 & 18,165 & $0.11 * * *$ & 10.87 & $\mathrm{Qtr}+1$ & $0.10 * * *$ & 8.22 \\
\hline $\mathrm{Qtr}+2$ & 288,720 & $0.03 * * *$ & 6.30 & $\mathrm{Qtr}+2$ & 17,325 & $0.09 * * *$ & 10.32 & $\mathrm{Qtr}+2$ & $0.06 * * *$ & 5.61 \\
\hline $\mathrm{Qtr}+3$ & 198,953 & $0.03 * * *$ & 4.94 & $\mathrm{Qtr}+3$ & 12,946 & $0.07 * * *$ & 7.37 & $\mathrm{Qtr}+3$ & $0.04 * * *$ & 3.77 \\
\hline Year +0 & 442,496 & $-0.10 * * *$ & -5.98 & Year +0 & 19,451 & $0.56 * * *$ & 24.63 & Year +0 & $0.66 * * *$ & 23.37 \\
\hline Year +1 & 395,088 & $0.04 * *$ & 2.35 & Year +1 & 19,089 & $0.55 * * *$ & 19.61 & Year +1 & $0.51 * * *$ & 15.64 \\
\hline Year +2 & 107,362 & $0.21 * * *$ & 6.78 & Year +2 & 8,800 & $0.52 * * *$ & 10.07 & Year +2 & $0.30 * * *$ & 5.03 \\
\hline \multicolumn{4}{|c|}{ After Law $=1$, Irish Likely $=0$} & \multicolumn{4}{|c|}{ After Law $=1$, Irish Likely $=1$} & \multicolumn{3}{|c|}{ difference $($ Irish Likely $=1-$ Irish Likely $=0)$} \\
\hline Time Pd & $\underline{\mathrm{N}}$ & Mean & tstat & Time Pd & $\underline{N}$ & $\underline{\text { Mean }}$ & tstat & Time Pd & Mean & $\underline{\text { tstat }}$ \\
\hline $\mathrm{Qtr}+0$ & 94,567 & $0.09 * * *$ & $\overline{5.63}$ & $\mathrm{Qtr}+0$ & 4,487 & $0.14 * * *$ & 4.63 & $\mathrm{Qtr}+0$ & 0.05 & 1.37 \\
\hline $\mathrm{Qtr}+1$ & 101,182 & $-0.06 * *$ & -2.11 & $\mathrm{Qtr}+1$ & 4,836 & -0.02 & -0.68 & $\mathrm{Qtr}+1$ & 0.04 & 1.01 \\
\hline $\mathrm{Qtr}+2$ & 93,272 & $-0.12 * * *$ & -3.52 & $\mathrm{Qtr}+2$ & 4,566 & -0.03 & -1.22 & $\mathrm{Qtr}+2$ & $0.09 * *$ & 2.08 \\
\hline $\mathrm{Qtr}+3$ & 73,862 & $-0.09 * * *$ & -5.06 & $\mathrm{Qtr}+3$ & 3,827 & 0.01 & 0.22 & $\mathrm{Qtr}+3$ & $0.10 * * *$ & 2.72 \\
\hline Year +0 & 110,252 & $0.30 * * *$ & 7.60 & Year +0 & 4,969 & $0.21 * * *$ & 2.66 & Year +0 & -0.09 & -1.00 \\
\hline Year +1 & 87,362 & $-0.28 * * *$ & -2.95 & Year +1 & 4,016 & -0.03 & -0.30 & Year +1 & $0.25 *$ & 1.90 \\
\hline Year +2 & 38,903 & $-0.67 * * *$ & -5.68 & Year +2 & 2,492 & $-0.42 * * *$ & -2.80 & Year +2 & 0.25 & 1.33 \\
\hline \multicolumn{4}{|c|}{ difference (After Law $=1$ - After Law $=0)$} & \multicolumn{4}{|c|}{ difference $($ After Law $=1-$ After Law $=0)$} & \multicolumn{3}{|c|}{ difference-in-difference } \\
\hline Time Pd & & Mean & $\underline{\text { tstat }}$ & Time Pd & & Mean & $\underline{\text { tstat }}$ & Time Pd & $\underline{\text { Mean }}$ & $\underline{\text { tstat }}$ \\
\hline $\mathrm{Qtr}+0$ & & $0.13 * * *$ & 7.49 & $\mathrm{Qtr}+0$ & & $-0.09 * * *$ & -2.96 & $\mathrm{Qtr}+0$ & $-0.23 * * *$ & -6.26 \\
\hline Qtr + 1 & & $-0.07 * *$ & -2.53 & $\mathrm{Qtr}+1$ & & $-0.13 * * *$ & -4.33 & $\mathrm{Qtr}+1$ & -0.06 & -1.36 \\
\hline $\mathrm{Qtr}+2$ & & $-0.16 * * *$ & -4.46 & $\mathrm{Qtr}+2$ & & $-0.13 * * *$ & -4.55 & $\mathrm{Qtr}+2$ & 0.03 & 0.68 \\
\hline Qtr + 3 & & $-0.12 * * *$ & -6.36 & Qtr + 3 & & $-0.07 * *$ & -2.03 & $\mathrm{Qtr}+3$ & 0.05 & 1.44 \\
\hline Year +0 & & $0.40 * * *$ & 9.35 & Year +0 & & $-0.35 * * *$ & -4.35 & Year +0 & $-0.75 * * *$ & -8.18 \\
\hline Year +1 & & $-0.32 * * *$ & -3.30 & Year +1 & & $-0.57 * * *$ & -5.88 & Year +1 & $-0.25 *$ & -1.84 \\
\hline \multirow[t]{10}{*}{ Year + 2} & & $-0.89 * * *$ & -7.23 & Year +2 & & $-0.94 * * *$ & -5.90 & Year +2 & -0.05 & -0.24 \\
\hline & & & & & & & & \multicolumn{3}{|c|}{$\begin{array}{l}\text { triple difference (repurchaser vs. all other } \\
\text { firms, 1984-2011) }\end{array}$} \\
\hline & & & & & & & & & Mean & tstat \\
\hline & & & & & & & & Qtr + 0 & $\overline{0.12}$ & $\overline{1.15}$ \\
\hline & & & & & & & & $\mathrm{Qtr}+1$ & $0.36 * *$ & 2.53 \\
\hline & & & & & & & & Qtr + 2 & $\mathbf{0 . 3 3} * * *$ & 2.59 \\
\hline & & & & & & & & $\mathrm{Qtr}+3$ & $0.24 *$ & 1.71 \\
\hline & & & & & & & & Year + 0 & $\mathbf{0 . 8 5} * *$ & 2.26 \\
\hline & & & & & & & & Year + 1 & $0.91 * *$ & 1.97 \\
\hline & & & & & & & & Year +2 & $2.16 * *$ & 2.55 \\
\hline
\end{tabular}


Overall, these results suggest that firms likely to be using a "Double Irish with a Dutch Sandwich" structure are doing one of two things: 1) explicitly conveying positive earnings information with OMR announcements, or 2) timing their announcements to correspond with periods where upcoming earnings are underestimated. I now examine the same predictions in a multiple regression setting in order to more explicitly control for other variables and factors that might influence or bias AFR. I estimate the following triple differencing specification in the six forecast timeframes where univariate evidence consistent with my predictions was found:

$A F R_{i, t}=\alpha+\beta_{1}$ After Law L $_{i, t}+\beta_{2}$ Irish Likely $_{i, t}+\beta_{3}$ Repurchaser $_{i, t}+$ $\beta_{4}\left(\right.$ After Law $_{i, t} *$ Irish Likely $\left._{i, t}\right)+\beta_{5}\left(\right.$ After Law $_{i, t} *$ Repurchaser $\left._{i, t}\right)+\beta_{6}\left(\right.$ Irish Likely $_{i, t} *$ Repurchaser $\left._{i, t}\right)+\beta_{7}\left(\right.$ After Law $_{i, t} *$ Irish Likely $_{i, t} *$ Repurchaser $\left._{i, t}\right)+\gamma \boldsymbol{X}_{i, t}+\varepsilon_{i, t}$.

Repurchaser is an indicator variable equal to one if a firm announces an OMR program during that observation's $\mathrm{I} / \mathrm{B} / \mathrm{E} / \mathrm{S}$ update period and $\boldsymbol{X}$ is a matrix of control variables (including the lagged value of AFR). The coefficient of $\beta_{7}$ represents the triple difference measure. I also calculate the incremental AFR for an "Irish Likely", "post-law" repurchasing firm by adding together all seven Beta coefficients; this is shown as a memo item in each panel. Results are reported in Table 5.

The results in Panel A are consistent with the univariate test results. The triple difference variable is positive in every specification and significant at the $10 \%$ level or better in nine of twelve specifications. The sum of the key coefficients (the incremental average $A F R$ for my key sample) is positive in every case, consistent with the idea that OMR announcements from "Irish Likely", post-law firms convey information about betterthan-expected earnings on average. (In unreported Wald tests, I find that these sums are greater than zero at the $1 \%$ significance level in all specifications.) Note that in Panel A that the coefficients of Lagged AFR are very low; this lack of autocorrelation in the dependent variable, combined with the use of clustering at the month-year level, reduce concerns that the standard errors in Table 5 are inconsistent (Bertrand et al. (2004)). 
Table 5: OLS Triple Difference Tests of Abnormal Forecast Revisions Using a Shock to Repurchase Costs

Caption: The dependent variables are Abnormal Forecast Revisions (AFRs), where an Abnormal Forecast Revision is defined as the change in median forecasted earnings-pershare (scaled by lagged firm price) minus the "expected change" in the analyst earningsper-share forecast. The "expected change" used in the AFR calculation is the same measure used in Table 2, Panel C. Only observations where the forecast revision does not contain a contemporaneous earnings announcement are included. AFR is scaled up by 1,000. Median analyst forecasts for the entire I/B/E/S database are trimmed at the 1st and 99th percentiles prior to the construction of AFR, and all observations with a lagged stock price of less than $\$ 1$ are dropped. "Time period" for the I/B/E/S forecast measures is defined in Table 1. The key independent variables are After Law, which is equal to one if the the observation is between June 2007 and the end of 2011 (and zero otherwise), Irish Likely, which is equal to one if a firm has at least two subsidiaries incorporated in Ireland, one subsidiary incorporated in the Netherlands, and one subsidiary incorporated in another tax haven country, as classified by Desai et al. (2006) (and zero otherwise), Repurchaser, which is equal to one if an open market repurchase announcement occurs during the forecast update period for a particular firm (and zero otherwise), and double and triple interactions between these three variables. All "lagged" control variables refer to values obtained one quarter prior to the current fiscal quarter, with the exception of Lagged ScaledCapEx, which consists of capital expenditures scaled by average cash-adjusted assets over the last four fiscal quarters, and Lagged AFR, which refers to the value of AFR in the previous month (I/B/E/S forecasts are updated on a monthly basis). All variables used in the regression are defined in the Appendix. All non-indicator accounting variables are winsorized at the 1st and 99th percentiles. OLS coefficients for all explanatory variables are reported. $\mathrm{t}$-statistics for all variables are reported in parentheses underneath the coefficients. Standard errors are adjusted for heteroskedasticity and clustered at the month-year level. $* * *, * *$ and $*$ indicate coefficients with statistically significant differences from zero at the $1 \%, 5 \%$ and $10 \%$ levels, respectively. 


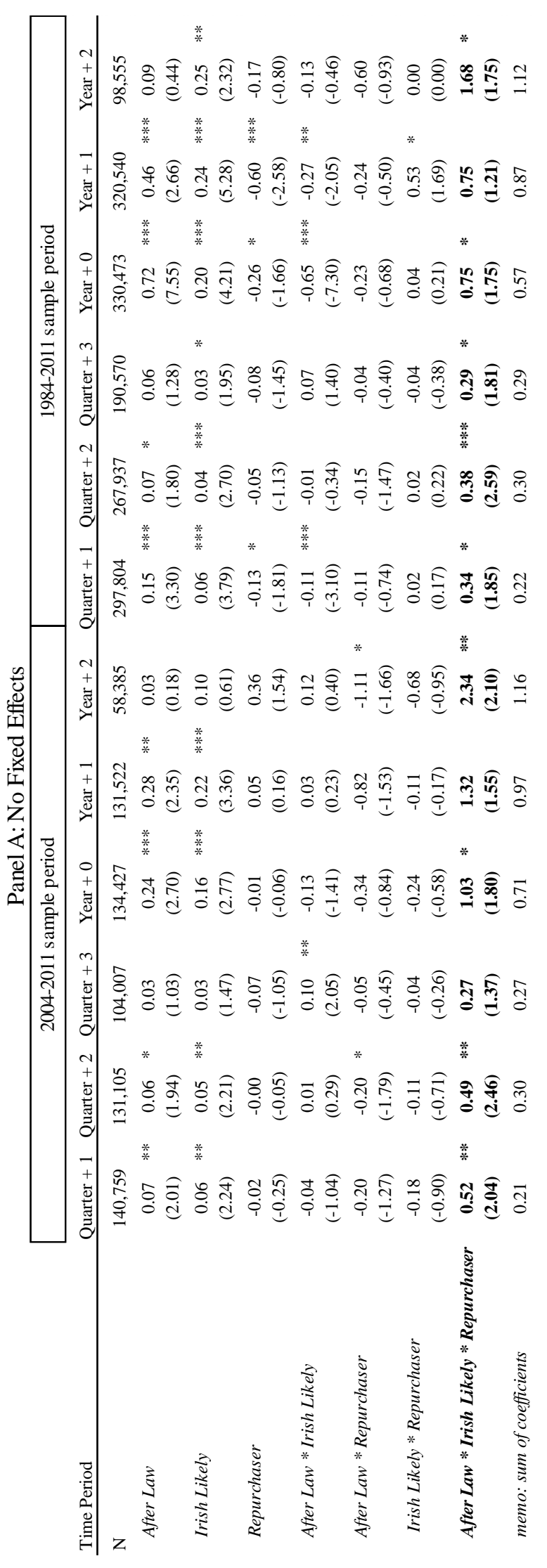




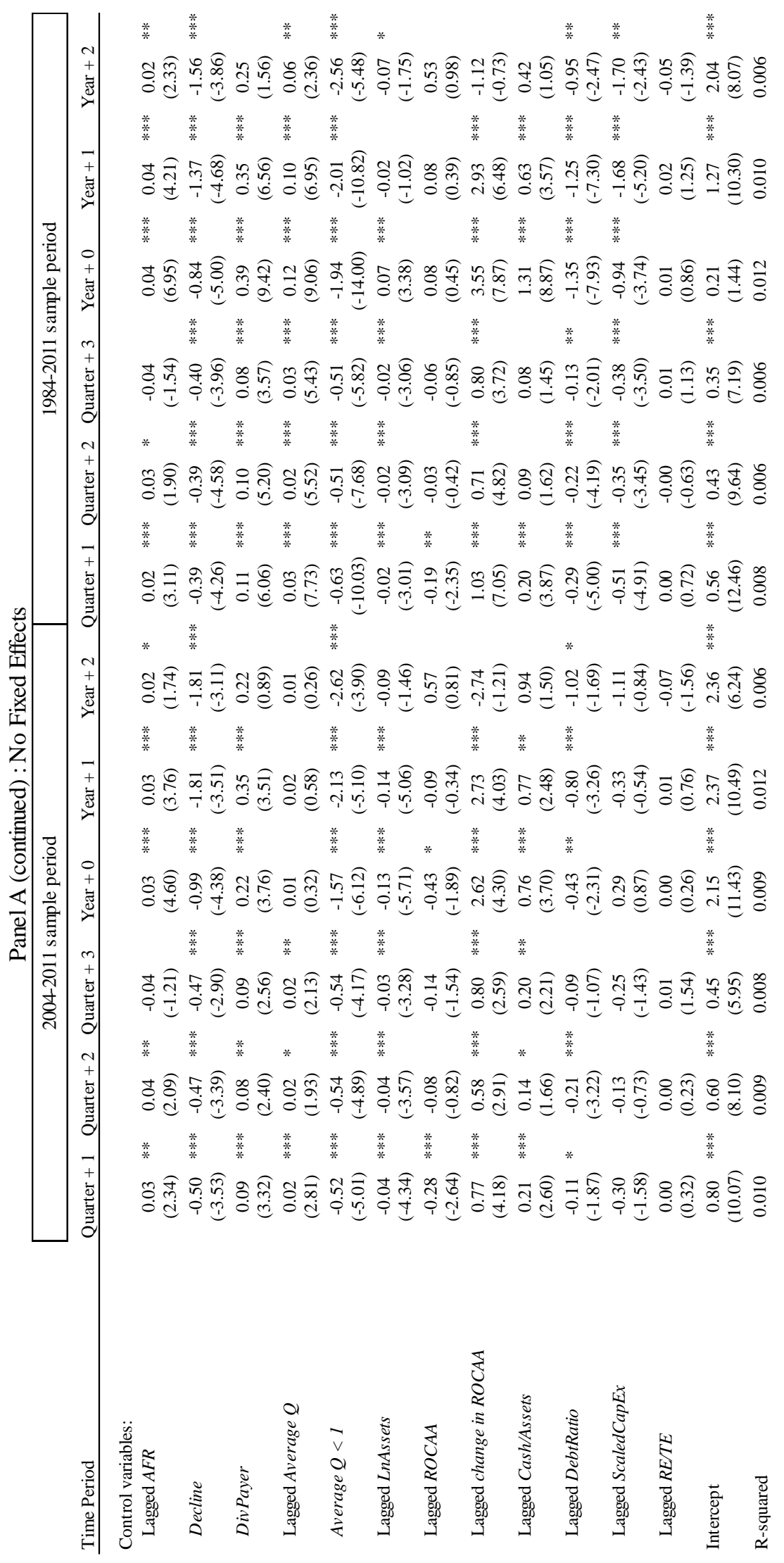




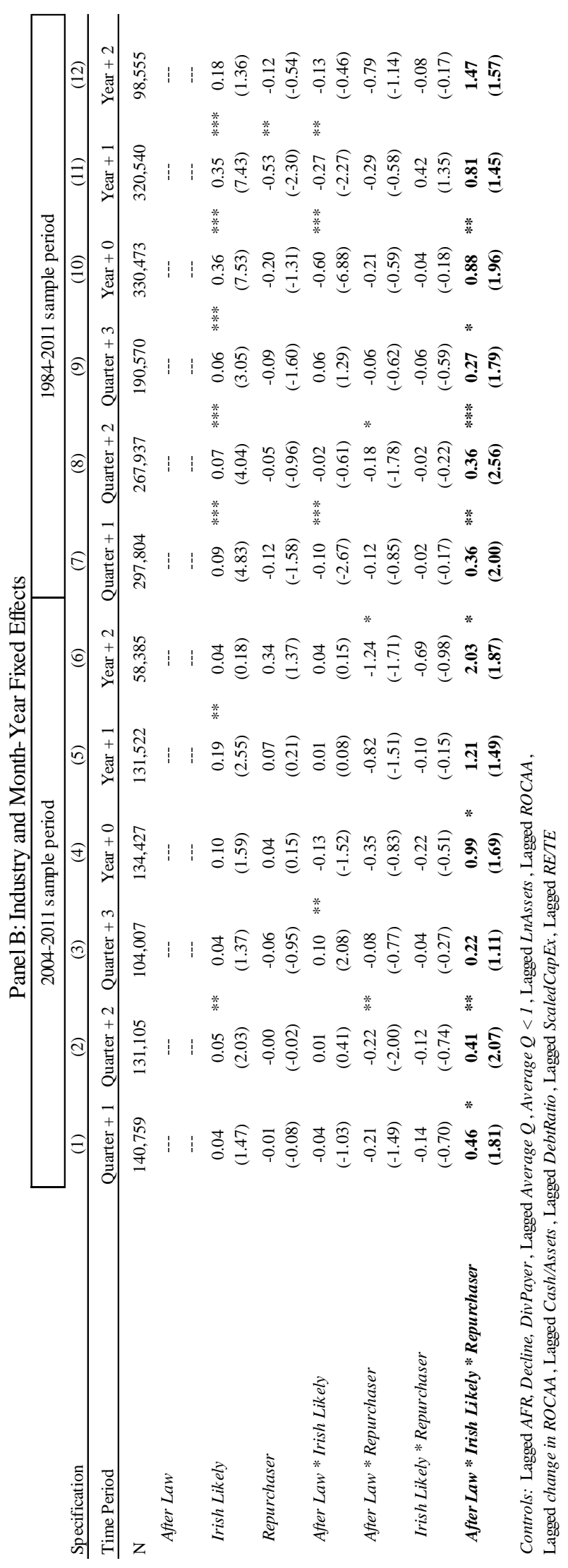




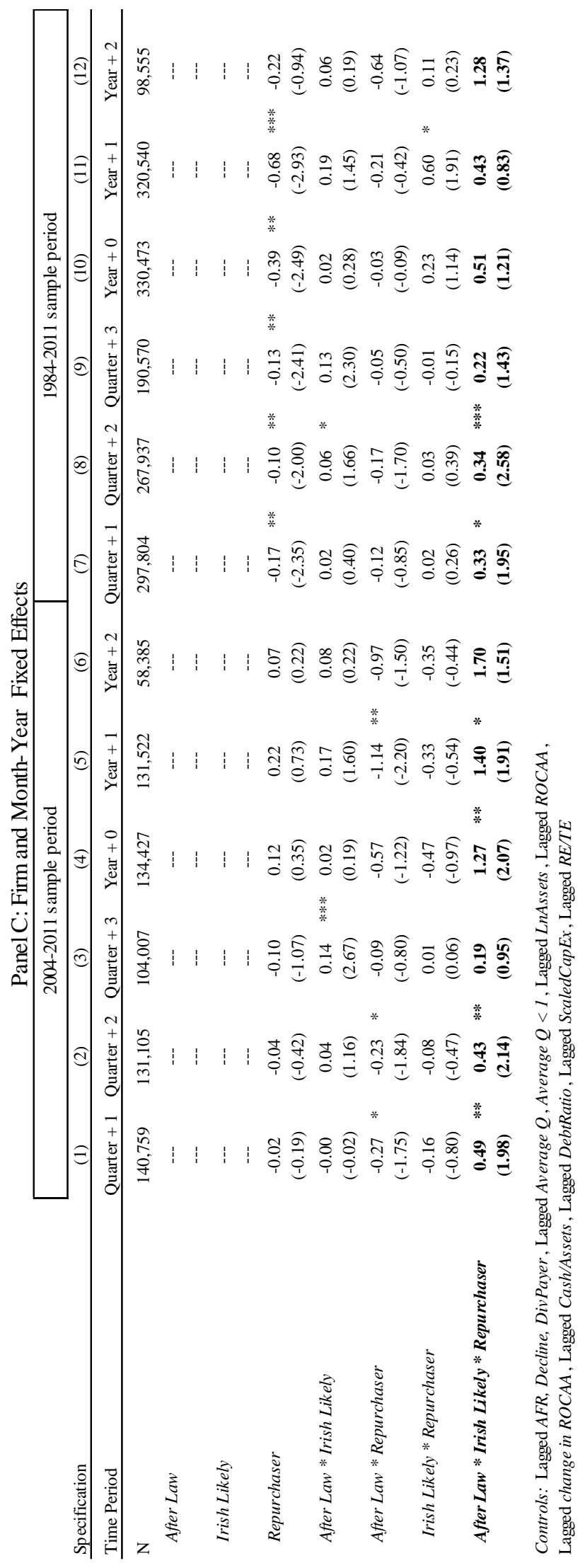


In Panel B, I re-estimate the key regressions including two-digit SIC code industry fixed effects and month-year fixed effects. ${ }^{21}$ The results are robust to this change; $\beta_{7}$ is positive in all cases and significant in eight of twelve specifications. Finally, Panel C presents results using firm and period fixed effects. $\beta_{7}$ is positive in all cases and statistically significant in six specifications.

These tests all use the novel measure of analyst forecast revisions described in Section II. In unreported tests I repeat the multiple regressions in Table 5 with an unadjusted measure of forecast revisions (raw median I/B/E/S analyst EPS revisions, scaled by lagged firm price). I obtain similar coefficients and significance levels for both $\beta_{7}$ and the sum of all Beta coefficients, suggesting that my results are not unique to the bias-adjusted definition of AFR used throughout the paper. This outcome is logical, since “optimism bias" common to all firm forecast revisions would be picked up by $\alpha$ and "sizerelated bias" should be picked up by my control variables.

To get a sense of the economic significance of these results, I begin by using the Panel C “Quarter +1 " $\beta_{7}$ coefficient in specification (1) (equal to 0.52, or 0.00052 without the "factor of 1,000" gross-up) and "un-scale" this estimated AFR impact by multiplying the median lagged share price among all Irish Likely, post-law firms (\$38.60). This gives a value of $0.00052 * \$ 38.60=\$ 0.020$, representing an upwards quarterly forecast revision of 2.0 cents (relative to other firms). Brous and Kini (1993) suggest that only one-fifth of analysts update their EPS estimates during a given forecast period, so this EPS estimate could theoretically have been as high as $2.0 * 5=10$ cents per quarter (40 cents per year) if non-updating analysts would have made similar revisions.

To estimate repurchase costs in "Irish Likely" firms, I start with data on the mean percentage of shares sought in the repurchase announcement obtained from the SDC database; this is 6.9\% for "Irish Likely" repurchasers from 2008-2011. The mean shares outstanding for these firms is 207 million. Bonaimé (2012) shows that, on average, $72.6 \%$ of an announced OMR will be completed within two years, so funds used for a typical repurchase are approximately $207,000,000 * .069 * .726 * \$ 38.60=\$ 400$ million. If firms

\footnotetext{
${ }^{21}$ For space reasons, the coefficients and significance of the control variables are omitted from the remaining
} panels and other multivariate tests. Results for these control variables remain similar throughout the study. 
were to fund their repurchases entirely with untaxed, offshore funds, the tax cost could be as large as $\$ 400 \mathrm{M} * .35=\$ 140$ million (assuming a 35\% U.S. corporate tax rate). This EPS impact is approximately $\$ 140 \mathrm{M} / 207 \mathrm{M}$ shares $=\$ 0.68$ per share (or an average of $\$ 0.34$ per year) under this "maximum cost" scenario. Given the high potential cost of repurchasing for these firms, it makes sense that firms affected by the shock would only repurchase if outsiders severely underestimate near-term earnings.

Finally, I examine whether the results in Tables 4 and 5 hold for the subsample of firms with subsidiaries in any tax haven country. This subsample is of interest for two reasons. First, the number of firms with subsidiaries in any haven is larger than the number of firms likely to have Double Irish structures. Second, these tests examine the idea that evidence of earnings information should be stronger in "Irish Likely" firms than the larger sample of firms with any haven.

The multiple regression tests using Any Haven in the three panels of Table 6 closely mirror those in Table 5. The triple difference coefficients are once again positive and generally significant in all panels. When the coefficients of all seven key variables are summed in Panel A, there is evidence consistent with positive incremental AFRs for this subsample, although these sums are generally lower than the corresponding sums using Irish Likely in Table 5. While these results suggest that the evidence of earnings information conveyed by costly repurchases is not unique to the (smaller) sample of "Irish Likely"-firms, the evidence is less strong in this larger sample. 
Table 6: OLS Triple Difference Tests using an Alternative Tax Haven Variable

Caption: The dependent variables are Abnormal Forecast Revisions (AFRs), where an Abnormal Forecast Revision is defined as the change in median forecasted earnings-pershare (scaled by lagged firm price) minus the "expected change" in the analyst earningsper-share forecast. The "expected change" used in the AFR calculation is the same measure used in Table 2, Panel C. Only observations where the forecast revision does not contain a contemporaneous earnings announcement are included. AFR is scaled up by 1,000. Median analyst forecasts for the entire $\mathrm{I} / \mathrm{B} / \mathrm{E} / \mathrm{S}$ database are trimmed at the 1 st and 99th percentiles prior to the construction of AFR, and all observations with a lagged stock price of less than $\$ 1$ are dropped. "Time period" for the $\mathrm{I} / \mathrm{B} / \mathrm{E} / \mathrm{S}$ forecast measures in Panel A is defined in Table 1. The key independent variables are After Law, which is equal to one if the the observation is between June 2007 and the end of 2011 (and zero otherwise), Any Haven, which is equal to one if a firm has at least one subsidiary incorporated in another tax haven country, as classified by Desai et al. (2006) (and zero otherwise), Repurchaser, which is equal to one if an open market repurchase announcement occurs during the forecast update period for a particular firm (and zero otherwise), and double and triple interactions between these three variables. All "lagged" control variables refer to values obtained one quarter prior to the current fiscal quarter, with the exception of Lagged ScaledCapEx, which consists of capital expenditures scaled by average cash-adjusted assets over the last four fiscal quarters, and Lagged AFR, which refers to the value of AFR in the previous month (I/B/E/S forecasts are updated on a monthly basis). All variables used in the regression are defined in the Appendix. All non-indicator accounting variables are winsorized at the 1st and 99th percentiles. OLS coefficients for all explanatory variables are reported. t-statistics for all variables are reported in parentheses underneath the coefficients. Standard errors are adjusted for heteroskedasticity and clustered at the month-year level. ***,** and * indicate coefficients with statistically significant differences from zero at the $1 \%, 5 \%$ and $10 \%$ levels, respectively. 


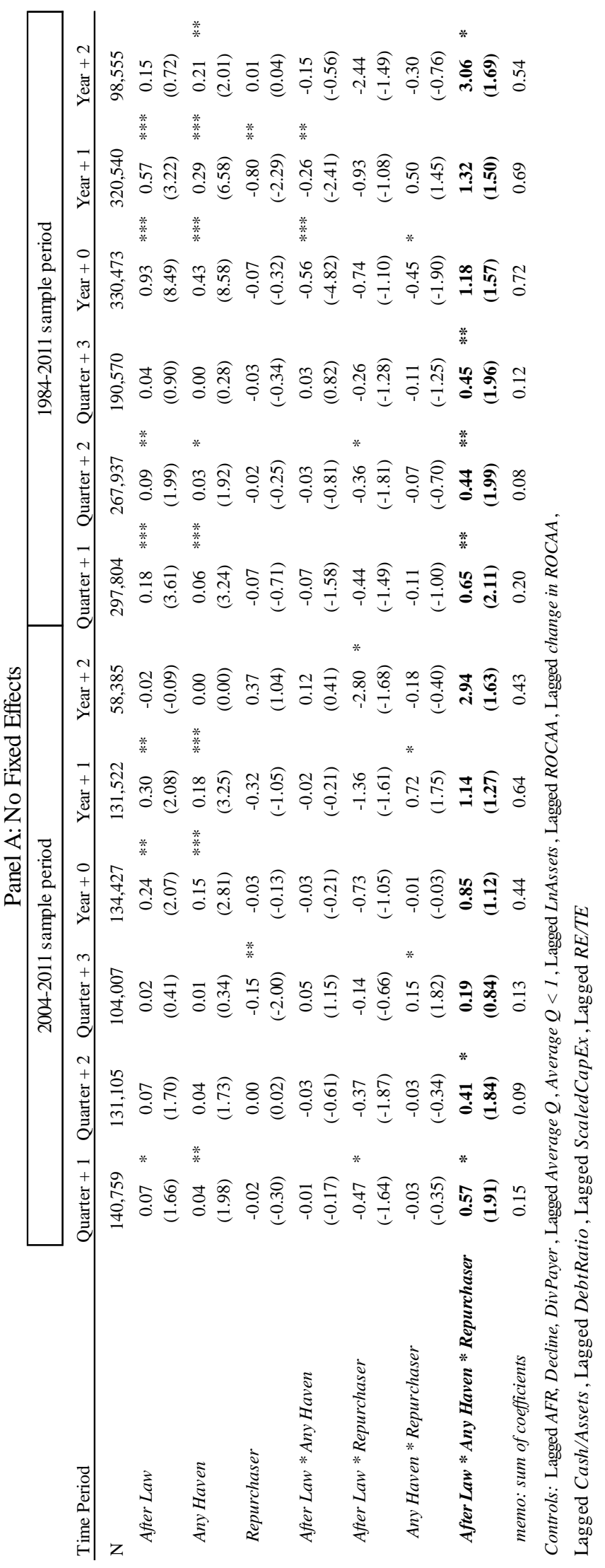




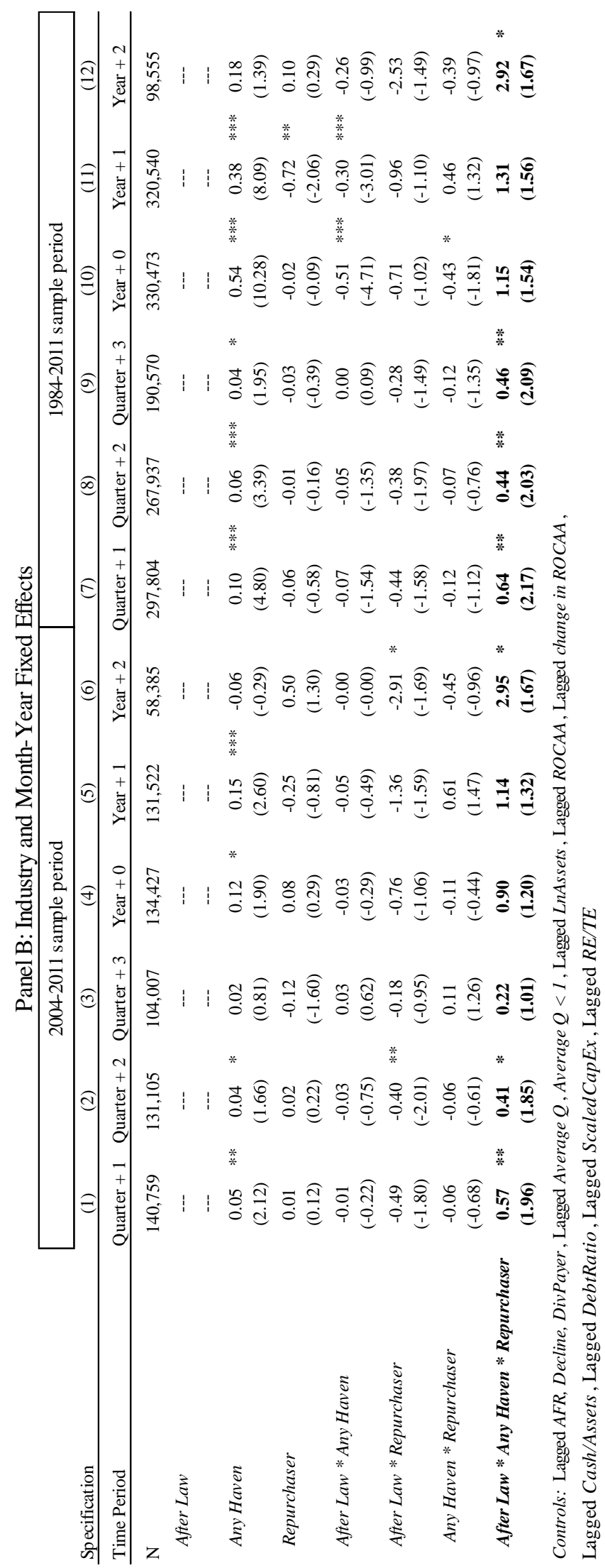




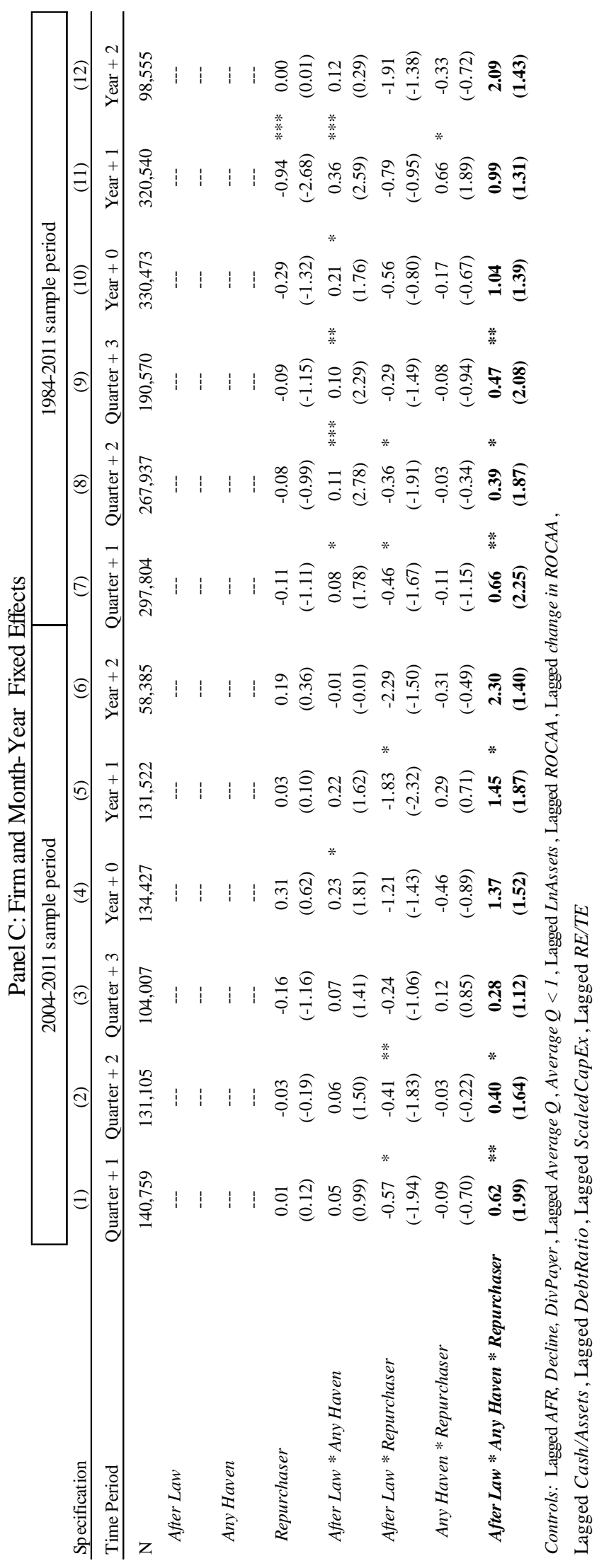




\section{V.B The Likelihood of Open Market Repurchase Announcements}

If the 2007 IRS regulation had the hypothesized effect on the repurchase motivations for tax haven-using firms, the frequency of open market repurchase program announcements from haven-using firms should have been affected as well. In other words, if repurchases become more costly for tax-avoiding firms after this regulation, these firms should announce repurchase programs less frequently when compared to their (non-taxavoiding) peers during this period.

I test this hypothesis using conditional logit specifications of the indicator variable Repurchaser on the indicator variable After Law and control variables. The conditional logit regressions are run for three samples: 1) Firms likely to be using "Double Irish" tax avoidance techniques (Irish Likely =1), 2) Firms unlikely to be using these techniques (Irish Likely $=0$ ), and 3) the full sample of firms, using an interaction term (After Law * Irish Likely) to test whether the likelihood of an OMR announcement is significantly different between the two types of firms. Firm fixed effects are included in all specifications to test whether the likelihood of an OMR announcement changes after the regulation within each firm. I include I/B/E/S monthly observations both with and without contemporaneous earnings announcements in this sample; unlike tests of forecast revisions, the dependent variable of interest should be largely unaffected by other information contained in an earnings announcement. 


\section{Table 7: Likelihood of Open Market Announcements}

Caption: The following table presents the results of conditional logit regressions of Repurchaser (which is equal to one if an open market repurchase announcement occurs during the forecast update period for a particular firm (and zero otherwise)) on After Law, which is equal to one if the observation is between June 2007 and the end of 2011 (and zero otherwise), Irish Likely, which is equal to one if a firm has at least two subsidiaries incorporated in Ireland, one subsidiary incorporated in the Netherlands, and one subsidiary incorporated in another tax haven country, as classified by Desai et al. (2006) (and zero otherwise), a double interaction between these two variables, control variables, and firm fixed effects. All "lagged" control variables refer to values obtained one quarter prior to the current fiscal quarter, with the exception of Lagged ScaledCapEx, which consists of capital expenditures scaled by average cash-adjusted assets over the last four fiscal quarters. All variables used in the regression are defined in the Appendix. All nonindicator accounting variables are winsorized at the 1st and 99th percentiles. Coefficients for all explanatory variables are reported. Z-statistics for all variables are reported in parentheses underneath the coefficients. $* * *, * *$ and $*$ indicate coefficients with statistically significant differences from zero at the $1 \%, 5 \%$ and $10 \%$ levels, respectively. 


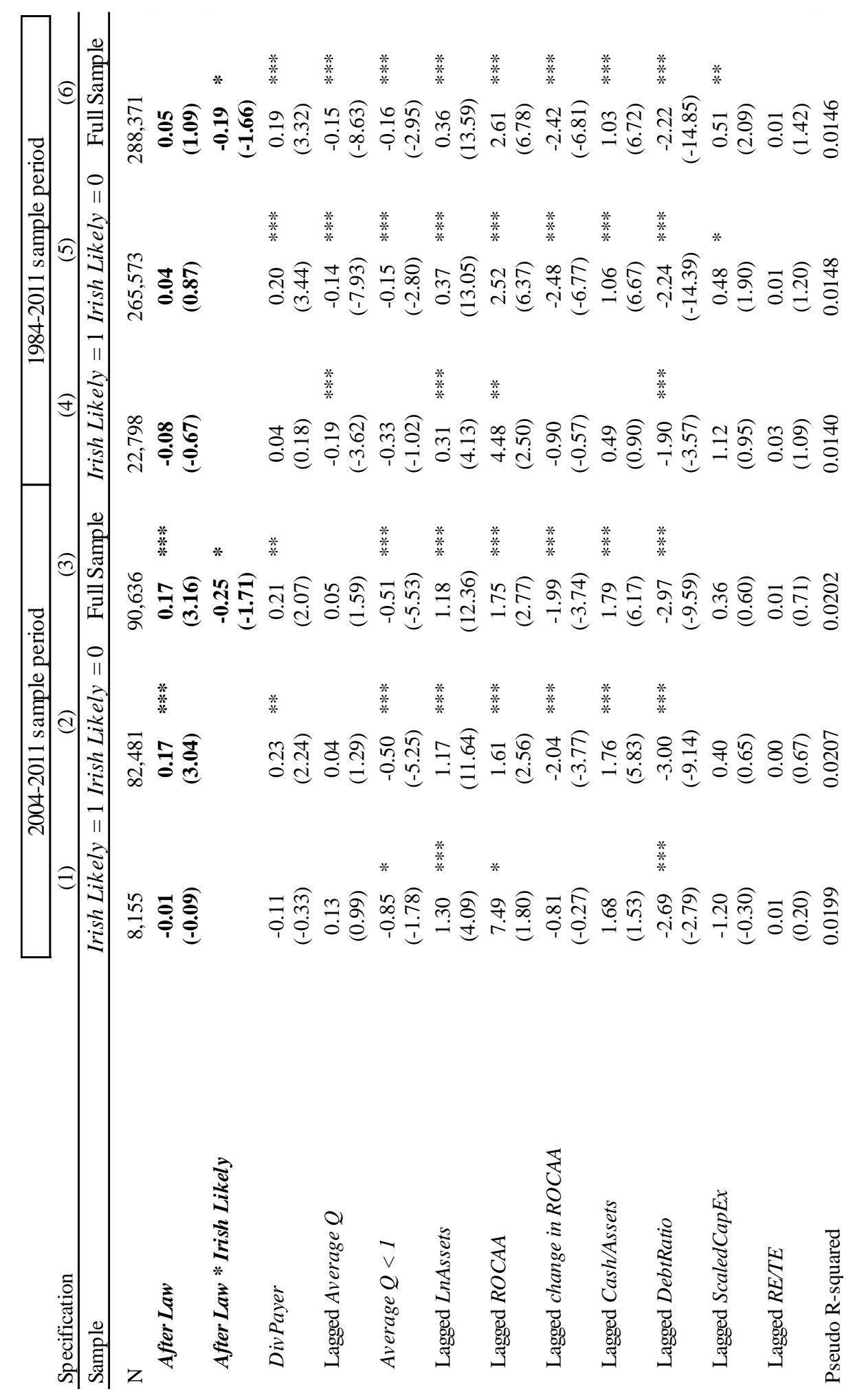


The results of this test are presented in Table 7. In specification (1), After Law is insignificantly different from zero in the 2004-2011 sample, suggesting that the likelihood of an OMR announcement from Irish Likely firms is similar before and after the 2007 law change (after controlling for other firm-level variables). However, the results are different for non-Irish Likely firms, as shown in specification (2); these firms are significantly more likely to announce an OMR program after the 2007 reform (perhaps due to weak economic conditions during this period and a desire to "prop up" their stock prices). Specification (3) includes both types of firms in the sample, and the negative interaction term After Law * Irish Likely confirms that Irish Likely firms announce fewer OMR programs compared with other firms after the regulation. Specifications (4)-(6) repeat these tests for the 19842011 sample and find similar results. Overall, these results are consistent with the 2007 regulation increasing repurchasing costs for "Irish Likely" firms, leading to (relatively) fewer OMR programs from these firms.

\section{V.C Changes in Actual Earnings Following Repurchase Announcements}

My tests to this point have largely focused on forecasted (rather than actual) earnings. The evidence thus far is only useful if 1) analysts can correctly assess which OMR announcements will be followed by actual repurchases, and 2) analyst earnings forecasts are consistent with realized earnings. To address the first concern, I examine whether analysts are generally able to predict which OMR announcements will be followed by actual repurchases. In unreported tests, I examine all observations from 2004-2011 (when actual repurchase data is available in Compustat) where an OMR announcement was not followed with actual repurchases within the next four quarters. I find significantly negative average AFRs in five of six forecast timeframes for this subsample of OMR announcements, suggesting that analysts were not "fooled" by these announcements.

To address the second concern, I examine post-OMR-announcement changes in actual earnings in "Irish Likely" firms after the IRS regulation. Lie (2005) suggests that "matched" earnings measures that compare repurchasers to matched, non-repurchasing firms are the most appropriate for tests, as an ideal matching procedure would control for 
a repurchaser's expected performance. ${ }^{22}$ To generate matched, non-repurchase-announcing firms, I use the propensity score matching (PSM) procedure developed by Heckman, Ichimura, and Todd $(1997,1998)$ create "nearest neighbor" matches as in Leuven and Sianesi (2003). I match on all key accounting control variables defined in Section II (matching on Decline is unnecessary since matches are determined within each quarteryear cluster). Since future operating performance should not be influenced by whether or not earnings announcements coincide with analyst forecast update periods in I/B/E/S, I again use observations both with and without contemporaneous earnings announcements.

Table 8 presents the mean values of these variables for both OMR-announcing and matched firms. With the exception of one variable, all of the mean firm characteristics are insignificantly different from one another at the $10 \%$ level of significance. Additionally, in untabulated results I find that lagged average abnormal accruals (constructed using the methodology in Kothari et al. (2005)) are insignificantly different between the treatment and matched samples. This reduces concerns that firms managing earnings downward in the quarter prior to an OMR announcement (documented by Gong, Louis, and Sun (2008)) might impact the results of these tests.

\footnotetext{
${ }^{22}$ These matching tests rely on two key assumptions: 1) the matching procedure was able to control for the most important predictors of earnings between paired repurchasing and non-repurchasing firms, and 2) any measured performance differences between sample and matched firms are primarily due to the sample firm's decision to repurchase and the motivations behind that repurchase.
} 
Table 8: Comparison of Repurchasing and Matching Firm Characteristics after Propensity Score Matching

Caption: This table presents the characteristics of open market repurchase-announcing firms and non-repurchasing matching firms from 1984-2011. The matching firms are the nearest-neighbor matches to repurchasing firms determined by a logit regression of Repurchaser (as defined in Table 7) on the characteristics listed below using the propensity score matching procedure developed by Leuven and Sianesi (2003). Summary statistics are presented for observations with available data for all variables below and one-quarterleading values of Return on Cash-Adjusted Assets (ROCAA). Separate logit regressions are run in each calendar quarter-year cluster.

$\begin{array}{lcrr}\text { Matching variable } & \text { Mean values } & & \text { t-stat of mean diff } \\ \text { DivPayer } & \text { Repurchaser } & \text { Matching } & -0.49 \\ \text { Lagged Average } Q & 0.443 & 0.446 & 1.87 \\ \text { Lagged LnAssets } & 1.885 & 1.848 & -0.09 \\ \text { Lagged ROCAA } & 6.406 & 6.409 & 0.10 \\ \text { Lagged change in ROCAA } & 0.045 & 0.045 & -1.44 \\ \text { Lagged Cash/Assets } & -0.002 & -0.001 & 1.49 \\ \text { Lagged ScaledCapEx } & 0.167 & 0.163 & 0.56 \\ \text { Lagged DebtRatio } & 0.074 & 0.073 & 0.94 \\ \text { Lagged RE/TE } & 0.189 & 0.186 & -0.18\end{array}$


Having paired repurchasing and non-repurchasing firms, I then calculate quarterover-quarter changes in ROCAA, starting with the quarter of the repurchase announcement. For example, the quarter " 0 " change compares quarters " 0 " and " 1 " (the quarter on which treatment and control firm operating performance is matched), the quarter " +1 " change compares quarters " $+1 "$ and " $+0 "$, and so on. In Table 9, I report the cumulative post-announcement changes in matched ROCAA for zero, one, two, four, and eight full quarters after the open market announcement. ${ }^{23}$ The reported ROCAA changes are winsorized at the $1^{\text {st }}$ and $99^{\text {th }}$ percentiles.

In the 2004-2011 period (Panel A), after "quarter +0 " (the OMR announcement quarter) the only significantly positive ROCAA changes are found in the "Irish Likely", "post-law" subsample. While other pre-reform subsamples have significantly positive ROCAA changes in the larger 1984-2011 sample period (Panel B), the changes in ROCAA are typically highest in the subsample of "Irish Likely", "post-law" repurchasers. For example, ROCAA changes in this subsample are about twice as large in magnitude as the changes in the "Irish Likely", "pre-law" subsample for my three longest measurement periods. The mean cumulative change in ROCAA for the key subsample is 0.018 four full quarters after the repurchase announcement, or an average increase of 0.36 percentage points per quarter (including the announcement quarter). This is an economically meaningful increase when compared to the $4.5 \%$ mean ROCAA in Table 8. Overall, the results in this table provide support for the earlier evidence using analyst forecasts.

${ }^{23}$ See the appendix for more details about the calculation of cumulative changes in matched ROCAA. 
Table 9: Matched Measures of Post-Announcement Operating Performance Caption: This table presents the mean differences in cumulative quarter-over-quarter changes in Return on Cash-Adjusted Assets (ROCAA) between open market repurchase announcing firms and non-repurchasing matching firms (determined by the propensity score matching procedure outlined in Table 9). All matched cumulative ROCAA measures are winsorized at the 1st and 99th percentiles. "Time period" for the I/B/E/S forecast measures is defined in Table 1. After Law is equal to one if the observation is between June 2007 and the end of 2011 (and zero otherwise). Irish Likely is equal to one if a firm has at least two subsidiaries incorporated in Ireland, one subsidiary incorporated in the Netherlands, and one subsidiary incorporated in another tax haven country, as classified by Desai et al. (2006) (and zero otherwise). ***, ** and * indicate significance using two-tailed t-tests at the $1 \%, 5 \%$ and $10 \%$ levels, respectively.

Panel A: Cumulative Changes in ROCAA, 2004-2011

\begin{tabular}{|lrlr|}
\hline \multicolumn{4}{|c|}{ Before law change, non-Irish-likely } \\
\hline & $\underline{\mathrm{N}}$ & $\underline{\text { Mean }}$ & $\underline{\underline{\text { tstat }}}$ \\
$\mathrm{qtr}(0)$ & 1,169 & 0.001 & 0.35 \\
$\mathrm{qtr}(0)$ through $\mathrm{qtr}(+1)$ & 1,094 & 0.001 & 0.38 \\
$\mathrm{qtr}(0)$ through $\mathrm{qtr}(+2)$ & 1,027 & 0.000 & 0.00 \\
$\mathrm{qtr}(0)$ through $\mathrm{qtr}(+4)$ & 884 & 0.001 & 0.43 \\
$\mathrm{qtr}(0)$ through $\mathrm{qtr}(+8)$ & 658 & -0.004 & -1.47
\end{tabular}

\begin{tabular}{|lrrr|}
\hline \multicolumn{4}{|c|}{ Before law change, Irish-likely } \\
\hline & $\underline{\mathrm{N}}$ & $\underline{\text { Mean }}$ & $\underline{\underline{\text { tstat }}}$ \\
$\mathrm{qtr}(0)$ & 113 & 0.002 & 0.37 \\
$\mathrm{qtr}(0)$ through $\mathrm{q} \operatorname{tr}(+1)$ & 110 & -0.002 & -0.32 \\
$\mathrm{qtr}(0)$ through $\operatorname{qt}(+2)$ & 105 & 0.004 & 0.92 \\
$\mathrm{qtr}(0)$ through $\operatorname{qt}(+4)$ & 94 & 0.009 & 1.45 \\
$\mathrm{qtr}(0)$ through $\operatorname{qt}(+8)$ & 75 & 0.000 & 0.04
\end{tabular}

\begin{tabular}{|c|c|c|c|}
\hline \multicolumn{4}{|c|}{ After law change, non-Irish-likely } \\
\hline & $\underline{\mathrm{N}}$ & $\underline{\text { Mean }}$ & $\underline{\text { tstat }}$ \\
\hline $\mathrm{qtr}(0)$ & 2,130 & 0.002 & $1.83 *$ \\
\hline $\operatorname{qtr}(0)$ through $q \operatorname{tr}(+1)$ & 2,008 & 0.001 & 0.96 \\
\hline qtr(0) through $\mathrm{qtr}(+2)$ & 1,847 & 0.002 & 1.35 \\
\hline $\operatorname{qtr}(0)$ through $\mathrm{qtr}(+4)$ & 1,243 & -0.001 & -0.46 \\
\hline $\operatorname{qtr}(0)$ through $\operatorname{qtr}(+8)$ & 580 & 0.000 & 0.03 \\
\hline
\end{tabular}

\begin{tabular}{|c|c|c|c|}
\hline \multicolumn{4}{|c|}{ After law change, Irish-likely } \\
\hline & $\underline{N}$ & Mean & $\underline{\text { tstat }}$ \\
\hline $\mathrm{qtr}(0)$ & 194 & 0.006 & $1.94 *$ \\
\hline $\operatorname{qtr}(0)$ through $\operatorname{qtr}(+1)$ & 183 & 0.004 & 1.08 \\
\hline $\operatorname{qtr}(0)$ through $\operatorname{qtr}(+2)$ & 173 & 0.009 & $2.01 * *$ \\
\hline $\mathrm{qtr}(0)$ through $\mathrm{qtr}(+4)$ & 110 & 0.018 & $2.24 * *$ \\
\hline $\operatorname{qtr}(0)$ through $\operatorname{qtr}(+8)$ & 44 & 0.022 & $1.93 *$ \\
\hline
\end{tabular}


Panel B: Cumulative Changes in ROCAA, 1984-2011

\begin{tabular}{|c|c|c|c|}
\hline \multicolumn{4}{|c|}{ Before law change, non-Irish-likely } \\
\hline & $\underline{\mathrm{N}}$ & Mean & $\underline{\text { tstat }}$ \\
\hline $\mathrm{qtr}(0)$ & 5,580 & 0.002 & $2.36 * *$ \\
\hline $\mathrm{qtr}(0)$ through $\mathrm{qtr}(+1)$ & 5,137 & 0.002 & $2.94 * * *$ \\
\hline $\mathrm{qtr}(0)$ through $\mathrm{qtr}(+2)$ & 4,683 & 0.001 & 0.55 \\
\hline $\mathrm{qtr}(0)$ through $\mathrm{qtr}(+4)$ & 3,877 & 0.002 & $1.96 * *$ \\
\hline $\mathrm{qtr}(0)$ through $\mathrm{qtr}(+8)$ & 2,695 & 0.002 & 1.18 \\
\hline
\end{tabular}

\begin{tabular}{|lrll|}
\hline \multicolumn{4}{|c|}{ Before law change, Irish-likely } \\
\hline & $\underline{\mathrm{N}}$ & $\underline{\underline{M} \text { ean }}$ & $\underline{\underline{\text { tstat }}}$ \\
$\mathrm{qtr}(0)$ & 397 & 0.005 & $2.05 * *$ \\
$\mathrm{qtr}(0)$ through $\mathrm{qtr}(+1)$ & 373 & 0.006 & $2.13 * *$ \\
$\mathrm{qtr}(0)$ through $\mathrm{qtr}(+2)$ & 346 & 0.004 & 1.32 \\
$\mathrm{qtr}(0)$ through $\mathrm{qtr}(+4)$ & 302 & 0.010 & $2.66 * * *$ \\
$\mathrm{qtr}(0)$ through $\mathrm{qtr}(+8)$ & 238 & 0.012 & 2.56
\end{tabular}

\begin{tabular}{|lrrr|}
\hline \multicolumn{4}{|c|}{ After law change, non-Irish-likely } \\
\hline & $\underline{\mathrm{N}}$ & $\underline{\text { Mean }}$ & $\underline{\underline{\text { tstat }}}$ \\
$\mathrm{qtr}(0)$ & 2,130 & 0.002 & $1.83 *$ \\
$\mathrm{qtr}(0)$ through $\mathrm{qtr}(+1)$ & 2,008 & 0.001 & 0.96 \\
$\mathrm{qtr}(0)$ through $\mathrm{qtr}(+2)$ & 1,847 & 0.002 & 1.35 \\
$\mathrm{qtr}(0)$ through $\mathrm{qtr}(+4)$ & 1,243 & -0.001 & -0.46 \\
$\mathrm{qtr}(0)$ through $\mathrm{qtr}(+8)$ & 580 & 0.000 & 0.03
\end{tabular}

\begin{tabular}{|c|c|c|c|}
\hline \multicolumn{4}{|c|}{ After law change, Irish-likely } \\
\hline & $\underline{\mathrm{N}}$ & Mean & tstat \\
\hline $\mathrm{qtr}(0)$ & $1 \overline{94}$ & $\overline{0.006}$ & $\overline{1.94} *$ \\
\hline $\mathrm{qtr}(0)$ through $\mathrm{qtr}(+1)$ & 183 & 0.004 & 1.08 \\
\hline $\mathrm{qtr}(0)$ through $\mathrm{qtr}(+2)$ & 173 & 0.009 & $2.01 * *$ \\
\hline $\mathrm{qtr}(0)$ through $\mathrm{qtr}(+4)$ & 110 & 0.018 & $2.24 * *$ \\
\hline $\mathrm{qtr}(0)$ through $\mathrm{qtr}(+8)$ & 44 & 0.022 & $1.93 *$ \\
\hline
\end{tabular}




\section{V.D Testing an Alternative Explanation: "Managing” EPS}

Some studies suggest that certain firms "manage" actual EPS by decreasing the EPS denominator through share repurchases (Bens et al. (2003), Hribar et al. (2006), Almeida et al. (forthcoming)). This leads to two questions relevant to my study: 1) do analysts typically take these "accretive" effects into account? 2) If so, could the results in Tables 4 and 5 be explained by Irish Likely firms announcing larger or more credible repurchase programs after the 2007 regulation (relative to non-Irish Likely firms)? I examine these questions in greater detail below.

First, I examine whether analysts typically account for accretive effects of repurchases in their forecasts. In an unreported test, I use the size of the repurchase program ((\%Sought, available in less than half of my OMR sample) as an independent variable in OLS specifications similar to those in Table 5 across all seven I/B/E/S timeframes. In untabulated results, I find that all twelve \%Sought coefficients are insignificantly different from zero. Additionally, five of the coefficients are negative (the opposite of what we would expect with accretive effects of repurchasing.) Since \%Sought may not be representative of some firms' actual repurchases, I repeat these tests in a subsample of firms who follow their OMR announcement with a large amount of immediate repurchases (i.e. they repurchase at least $1 \%$ of their shares outstanding within the first full quarter after the announcement, based on a similar measure of repurchase announcement credibility from Lie (2005)) and obtain similar results. Overall, these tests fail to find any evidence that analysts in my sample meaningfully account for EPS accretion in their forecasts.

I further examine whether Irish Likely firms appear to announce larger or more credible repurchase programs relative to non-Irish Likely firms after the 2007 regulation. First, I find that the announced size of the repurchase program stays basically unchanged for both types of firms before and after the regulation; for Irish Likely firms, the mean $\%$ Sought is $6.9 \%$ in both periods, while the non-Irish Likely firm measure increases very slightly from $8.0 \%$ to $8.2 \%$. Next, I investigate any changes in the credibility of repurchase programs by examining actual share repurchases. From 2004-2011, the percentage of Irish Likely firms that follow OMR announcements with actual repurchases in the following four quarters decreases from $97.8 \%$ (before the regulation) to $97.1 \%$ (after the regulation), 
while this measure increases from $88.1 \%$ to $89.6 \%$ in non-Irish Likely firms. This suggests that repurchase credibility actually becomes stronger in non-Irish Likely firms after the reform, which is again inconsistent with accretive effects explaining our results. Finally, I examine both the size and credibility of repurchase programs by calculating the percentage of actual shares repurchased within the first full quarter after the announcement (\%Repurchased). For Double Irish firms, average \%Repurchased increases from 3.3\% (before the regulation) to $3.5 \%$ (after the regulation), but \%Repurchased actually increases by more in non-Irish Likely firms (from 3.0\% to 3.6\%) over this same period. This suggest that increases in Irish Likely firms' OMR program size and credibility (from before to after the law) are less than similar changes in non-Irish Likely firms, again making it unlikely that accretive effects driven by changes in repurchase program size or credibility in Double Irish firms can explain this study's key findings. Taken together, these tests all suggest that main AFR results in the paper are not due to the accretive effect of repurchases on EPS. 


\section{CHAPTER 5 - CONCLUSION}

Two important results emerge from this study. First, I show that evidence consistent with unfavorable earnings information conveyed by OMR announcements in past studies may have been due to undetected biases in those studies' proxies for earnings expectations. Second, I examine unique subsamples of firms where repurchasing costs were likely to be high: firms that utilize offshore subsidiaries to store untaxed profits. An IRS regulation in 2007 effectively generated new repurchasing costs for these firms, allowing me to test whether these costs were accompanied by upward revisions in earnings expectations after OMR announcements. I find strong evidence of positive average abnormal forecast revisions in these subsamples of repurchasers, especially in firms where costs are likely to be the highest (those likely to be using a "Double Irish with a Dutch Sandwich" tax shelter structure).

To my knowledge, this is the first study to link these particular costs with the likelihood of a repurchase program announcement and with positive revisions in both forecasted and actual earnings. Even if managers in tax haven-using firms are not explicitly signaling earnings through their repurchase announcements, this study suggests that the announcements themselves may still contain meaningful information about upcoming firm earnings. 


\section{BIBLIOGRAPHY}




\section{BIBLIOGRAPHY}

Almeida, Heitor, Vyacheslav Fos, and Mathias Kronlund, The Real Effects of Share Repurchases, forthcoming in Journal of Financial Economics.

Babenko, Ilona, Yuri Tserlukevich, and Alexander Vedrashko, 2012, The Credibility of Open Market Share Repurchase Signaling, Journal of Financial and Quantitative Analysis 47, 1059-1088.

Bagnoli, Mark, Roger Gordon, and Barton L. Lipman, 1989, Stock Repurchase as a Takeover Defense, Review of Financial Studies 2, 423-442.

Bagwell, Laurie Simon, 1991, Share Repurchase and Takeover Deterrence, The RAND Journal of Economics 1991, 72-88.

Bartov, Eli, 1991, Open-market stock repurchases as signals for earnings and risk changes. Journal of Accounting and Economics 14, 275-294.

Bens, Daniel A., Venky Nagar, Douglas J. Skinner, and M.H. Franco Wong, 2003, Employee stock options, EPS dilution, and stock repurchases, Journal of Accounting and Economics 36, 51-90.

Berk, Jonathan B. and Richard C. Green, 2004, Mutual Fund Flows and Performance in Rational Markets, Journal of Political Economy 112 1269-1295. 
Bertrand, Marianne, Esther Duflo, and Sendhil Mullainathan, 2004, How Much Should We Trust Differences-in-Differences Estimates? Quarterly Journal of Economics 119, 249-275.

Bhattacharya, Sudipto, 1979, Imperfect information, dividend policy, and "the bird in the hand" fallacy, Bell Journal of Economics 10, 259-270.

Billett, Matthew T. and Hui Xue, 2007, The Takeover Deterrent Effect of Open Market Share Repurchases, Journal of Finance 62, 1827-1850.

Billett, Matthew T. and and Miaomiao Yu, Asymmetric Information, Financial Reporting, and Open Market Share Repurchases, forthcoming in Journal of Financial and Quantitative Analysis.

Bonaimé, Alice Adams, 2012, Repurchases, Reputation, and Returns, Journal of Financial and Quantitative Analysis 47, 469-491.

Brav, Alon, John R. Graham, Campbell R. Harvey, and Roni Michaely, 2005, Payout policy in the 21st century, Journal of Financial Economics 77, 483-527.

Brous, Peter, 1992, Common stock offerings and earnings expectations: A test of the release of unfavorable information, Journal of Finance 47, 1517-1526.

Brous, Peter A. and Omesh Kini, 1993, A reexamination of analysts' earnings forecasts for takeover targets, Journal of Financial Economics 33, 201-225.

Chan, Konan, David L. Ikenberry, Inmoo Lee, and Yanzhi Wang, 2010, Share repurchases as a potential tool to mislead investors, Journal of Corporate Finance 16, 137-158. 
Chen, Kevin C. W. and Michael P. Schoderbek, 2000, The 1993 Tax Rate Increase and Deferred Tax Adjustments: A Test of Functional Fixation, Journal of Accounting Research 38, 23-44.

Christie, Andrew, 1987, On cross-sectional analysis in accounting research, Journal of Accounting and Economics 9, 231-258.

Comment, Robert and Gregg A. Jarrell, 1991, The Relative Signalling Power of DutchAuction and Fixed-Price Tender Offers and Open-Market Share Repurchases, Journal of Finance 46, 1243-1271.

Dann, Larry Y., Ronald W. Masulis, and David Mayers, 1991, Repurchase tender offers and earnings information, Journal of Accounting and Economics 14, 217-251.

Desai Mihir A., C. Fritz Foley, and James R. Hines Jr., 2006, The demand for tax haven operations, Journal of Public Economics 90, 513-531.

Devos, Erik, Palani-Rajan Kadapakkam, and Srinivasan Krishnamurthy, 2009, How do mergers create value? A comparison of taxes, market power, and efficiency improvements as explanations for synergies, Review of Financial Studies 22, 11791211.

Dharmapala, Dhammika, C. Fritz Foley, and Kristen Forbes, 2011, Watch what I do, not what I say: the unintended consequences of the Homeland Investment Act, Journal of Finance 66, 753-788.

Dittmar, Amy K., 2000, Why Do Firms Repurchase Stock?, Journal of Business 73, 331355. 
Dittmar, Amy K. and Laura Field, Can managers time the market? Evidence using repurchase price data, forthcoming in Journal of Financial Economics.

D'Mello, Ranjan and Pervin K. Shroff, 2000, Equity Undervaluation and Decisions Related to Repurchase Tender Offers: An Empirical Investigation, Journal of Finance 55, 2399-2424.

Fama, Eugene and Kenneth French, 1993, Common risk factors in the returns on bonds and stocks, Journal of Financial Economics 33, 3-56.

Faulkender, Michael and Mitchell Petersen, 2012, Investment and Capital Constraints: Repatriations Under the American Jobs Creation Act, Review of Financial Studies 25, 3351-3388.

Foley, C. Fritz, Jay C. Hartzell, Sheridan Titman, and Garry Twite, 2007, Why do firms hold so much cash? A tax-based explanation, Journal of Financial Economics 86, 579607.

Gong, Guojin, Henock Louis, and Amy X. Sun, 2008, Earnings Management and Firm Performance Following Open-Market Repurchases, Journal of Finance 63, 947-986.

Griffin, Paul and Ning Zhu, 2010, Accounting rules? Stock buybacks and stock options: Additional evidence, Journal of Contemporary Accounting \& Economics 6, 1-17.

Grullon, Gustavo and Roni Michaely, 2002, Dividends, Share Repurchases, and the Substitution Hypothesis, Journal of Finance 57, 1649-1684.

Grullon, Gustavo and Roni Michaely, 2004, The Information Content of Share Repurchase Programs, Journal of Finance 59, 651-680. 
Gu, Zhaoyang and Joanna Shuang Wu, 2003, Earnings skewness and analyst forecast bias, Journal of Accounting and Economics 35, 5-29.

Heckman, James, Hidehiko Ichimura, and Petra Todd, 1997, Matching as an Econometric Evaluation Estimator: Evidence from Evaluating a Job Training Programme, Review of Economic Studies 64, 605-654.

Heckman, James, Hidehiko Ichimura, and Petra Todd, 1998, Matching as an Econometric Evaluation Estimator, Review of Economic Studies 65, 261-294.

Hoberg, Gerard, Gordon Phillips, and Nagpurnanand Prabhala, 2014, Product Market Threats, Payouts, and Financial Flexibility, Journal of Finance 69, 293-324.

Hribar, Paul, Nicole Thorne Jenkins, and W. Bruce Johnson, 2006, Stock repurchases as an earnings management device, Journal of Accounting and Economics 41, 3-27.

Ikenberry, David, Josef Lakonishok, and Theo Vermaelen, 1995, Market underreaction to open market share repurchases, Journal of Financial Economics 39, 181-208.

Jagannathan, Murali, and Clifford Stephens, 2003, Motives for Multiple Open-Market Repurchase Programs, Financial Management 32, 71-91.

Jagannathan, Murali, Clifford Stephens, and Michael Weisbach, 2000, Financial flexibility and the choice between dividends and stock repurchases, Journal of Financial Economics 57, 355-384.

Jensen, Michael, 1986, Agency Costs of Free Cash Flow, Corporate Finance, and Takeovers, American Economic Review 76, 323-329. 
Jensen, Michael C., William H. Meckling, 1976, Theory of the Firm: Managerial Behavior, Agency Costs and Ownership Structure, Journal of Financial Economics 4, 305-360.

John, Kose and Joseph Williams, 1985, Dividends, Dilution and Taxes: A Signaling Equilibrium, Journal of Finance 40, 1053-1070.

Kahle, Kathleen M, 2002, When a buyback isn't a buyback: open market repurchases and employee options, Journal of Financial Economics 63, 335-261.

Kim, Sangwan, Andrew Schmidt, and Kelly Wentland, 2014, Analyst Forecasts and the Permanence of the Tax Changes Component of Earnings, North Carolina State University working paper.

Kothari, S.P., Andrew J. Leone, and Charles E. Wasley, 2005, Performance matched discretionary accrual measures, Journal of Accounting and Economics 39, 163-197.

Lang, Larry HP and Robert H. Litzenberger, 1989, Dividend announcements: cash flow signalling vs. free cash flow hypothesis?, Journal of Financial Economics 24, 181191.

Leuven, Edwin and Barbara Sianesi, 2003, "PSMATCH2: Stata module to perform full Mahalanobis and propensity score matching, common support graphing, and covariate imbalance testing", http://ideas.repec.org/c/boc/bocode/s432001.html, version 4.0.6.

Lie, Erik, 2005, Operating performance following open market share repurchase announcements, Journal of Accounting and Economics 39, 411-436.

Louis, Henock and Hal White, 2007, Do managers intentionally use repurchase tender offers to signal private information? Evidence from firm financial reporting behavior, Journal of Financial Economics 85, 205-233. 
Louis, Henock, Amy X. Sun, and Oktay Urcan, 2013, Do Analysts Sacrifice Forecast Accuracy for Informativeness? Management Science 59, 1688-1708.

Martin, Xiumin, Maryjane Rabier, and Emanuel Zur, 2015, Dodging Repatriation Tax Evidence from Domestic and Foreign M\&As, Washington University in St. Louis working paper.

Massa, Massimo, Zahid Rehman, and Theo Vermaelen, 2007, Mimicking Repurchases, Journal of Financial Economics 84, 624-666.

McConnell, John J. and Erik Lie, 1998, Earnings signals in fixed-price and Dutch auction self-tender offers, Journal of Financial Economics 49, 161-186.

Miller, Merton H. and Franco Modigliani, 1966, Some Estimates of the Cost of Capital to the Electric Utility Industry, 1954-1957, American Economic Review 56, 333-391.

Miller, Merton H. and Kevin Rock, 1985, Dividend Policy under Asymmetric Information, Journal of Finance 40, 1031-1051.

O'Brien, Patricia, 1988, Analysts' forecasts as earnings expectations, Journal of Accounting and Economics 10, 187-221.

Ofer, Aharon R. and Anjan V. Thakor, 1987, A Theory of Stock Price Responses to Alternative Corporate Cash Disbursement Methods: Stock Repurchases and Dividends, Journal of Finance 42, 365-394.

Pauls, William R. Esq. and H. Karl Zeswitz, Jr., Esq., 2011, A Gambit Vanquished: The Rise and Fall of the "Killer B”, Tax Management Memorandum 419, 1-17. 
Peyer, Urs and Theo Vermaelen, 2009, The nature and persistence of buyback anomalies, Review of Financial Studies 22, 1693-1745.

Plumlee, Marlene A., 2003, The Effect of Information Complexity on Analysts' Use of That Information, Accounting Review 78, 275-296.

Rau, Raghavendra and Theo Vermaelen, 2002. Regulation, taxes, and share repurchases in the United Kingdom, Journal of Business 75, 245-282.

Skinner, Douglas J., 2008, The Evolving Relation Between Earnings, Dividends, and Stock Repurchases, Journal of Financial Economics 87, 582-609.

Stephens, Clifford P. and Michael S. Weisbach, 1998, Actual Share Reacquisitions in Open-Market Repurchase Programs, Journal of Finance 53, 313-333.

Vermaelen, Theo, 1981, Common stock repurchases and market signaling: An empirical study, Journal of Financial Economics 9, 139-183.

Vermaelen, Theo, 1984, Repurchase Tender Offers, Signaling, and Managerial Incentives, Journal of Financial and Quantitative Analysis 19, 163-181 
APPENDIX 


\section{APPENDIX}

\begin{tabular}{|c|c|}
\hline $\begin{array}{l}\text { Abnormal } \\
\text { Forecast } \\
\text { Revision (AFR) }\end{array}$ & $\begin{array}{l}\qquad A F R_{i, t}=F R_{i, t}-E\left(F R_{i, t}\right) \\
\text { Data for this measure are obtained from } \mathrm{I} / \mathrm{B} / \mathrm{E} / \mathrm{S} \text {. } F R \text { is the median } \\
\text { revision in earnings per share (EPS) for firm } i \text { in month } t \text {, scaled by } \\
\text { the stock price of the firm. Price scaling is used to reduce } \\
\text { measurement error in the forecasts (Christie }(1987)) . E(F R) \text { is the } \\
\text { "expected" revision in EPS for firm } i \text { in month } t \text {. The construction of } \\
E(F R) \text { is outlined in Section II of the paper. } A F R \text { is calculated for } \\
\text { seven timeframes: the next four quarters (including the current } \\
\text { quarter) and three years (including the current year). "Quarter + } 0 \text { " } \\
\text { indicates the current financial quarter as of the forecast revision, } \\
\text { "Quarter + 1" indicates the next financial quarter, and so on. }\end{array}$ \\
\hline After Law & $\begin{array}{l}\text { An indicator variable equal to one if the date of the observation is } \\
\text { between June } 2007 \text { and the end of } 2011 \text { (and zero otherwise). }\end{array}$ \\
\hline Any Haven & $\begin{array}{l}\text { An indicator variable equal to one if the firm has at least one } \\
\text { subsidiary incorporated in another tax haven country, as classified } \\
\text { by Desai } \text { et al. (2006) (and zero otherwise). }\end{array}$ \\
\hline Average Q & $\begin{array}{l}\text { The market value of equity plus the book value of liabilities, all } \\
\text { divided by the book value of assets ("atq"). Average Q is calculated } \\
\text { using the following operations of Compustat data items: ("atq" - } \\
\text { "ceqq" + ("cshoq" * "prccq") / "atq". In tests where Average } Q<1 \\
\text { is also used as an explanatory variable, values of Average Q below } \\
\text { one are set equal to one. }\end{array}$ \\
\hline Average $Q<1$ & $\begin{array}{l}\text { An indicator variable equal to one if an observation's Average Q (as } \\
\text { defined above) is less than one. }\end{array}$ \\
\hline Cash/Assets & $\begin{array}{l}\text { Cash and cash equivalents divided by total assets (Compustat data } \\
\text { item "cheq" divided by "atq") }\end{array}$ \\
\hline DebtRatio & $\begin{array}{l}\text { The sum of short-term debt (Compustat data item "sd") and long } \\
\text { term debt ("dlttq") divided by total assets ("atq"). }\end{array}$ \\
\hline Decline & $\begin{array}{l}\text { An indicator variable equal to one when the two-month-lagged } \\
\text { Smoothed U.S. Recession Probability is .10 or greater. Data on } \\
\text { U.S. Recession Probability is provided by the St. Louis Fed } \\
\text { website: } \\
\text { http://alfred.stlouisfed.org/series? seid=RECPROUSM156N. }\end{array}$ \\
\hline
\end{tabular}




\begin{tabular}{|c|c|}
\hline DivPayer & $\begin{array}{l}\text { An indicator variable equal to one if the one-quarter-lagged } \\
\text { Div/Price ratio for a particular firm is greater than zero (and zero } \\
\text { otherwise) }\end{array}$ \\
\hline AvgHistRevision & $\begin{array}{l}\text { The mean of all price-scaled median forecast revisions for a firm } \\
\text { over its entire } \mathrm{I} / \mathrm{B} / \mathrm{E} / \mathrm{S} \text { listing period. }\end{array}$ \\
\hline Irish Likely & $\begin{array}{l}\text { An indicator variable equal to one if the firm has at least two } \\
\text { subsidiaries incorporated in Ireland, one subsidiary incorporated in } \\
\text { the Netherlands, and one subsidiary incorporated in another tax } \\
\text { haven country, as classified by Desai et al. (2006) (and zero } \\
\text { otherwise). }\end{array}$ \\
\hline LnAssets & The natural log of firm assets (Compustat data item "atq") \\
\hline \%Sought & $\begin{array}{l}\text { The percentage of shares sought in an open market repurchase } \\
\text { announcement. Obtained from the Securities Data Corporation's } \\
\text { Mergers and Acquisitions database. }\end{array}$ \\
\hline$\%$ Repurchased & $\begin{array}{l}\text { The percentage of actual shares repurchased (relative to total shares } \\
\text { outstanding) through the first full quarter after an OMR } \\
\text { announcement. Calculated as Compustat item "cshopq" divided by } \\
\text { "cshoq". }\end{array}$ \\
\hline RankSize & $\begin{array}{l}\text { The percentile rank of firm } i \text { 's size in assets (Compustat data item } \\
\text { "atq") compared to all other Compustat-listed firms in a given } \\
\text { quarter. The percentile rank is input into the regressions as its } \\
\text { decimal equivalent (i.e. values between } 0 \text { and } 1 \text { ) in order to make the } \\
\text { coefficient values more comparable to UpwardEPS. }\end{array}$ \\
\hline $\mathrm{RE} / \mathrm{TE}$ & $\begin{array}{l}\text { Retained earnings (Compustat data item "req") divided by total } \\
\text { equity (Compustat data item "seqq") }\end{array}$ \\
\hline Repurchaser & $\begin{array}{l}\text { An indicator variable equal to one if an OMR announcement occurs } \\
\text { during the forecast update period for a particular firm (and zero } \\
\text { otherwise) }\end{array}$ \\
\hline $\begin{array}{l}\text { Return on Cash- } \\
\text { Adjusted Assets } \\
\text { (ROCAA) }\end{array}$ & 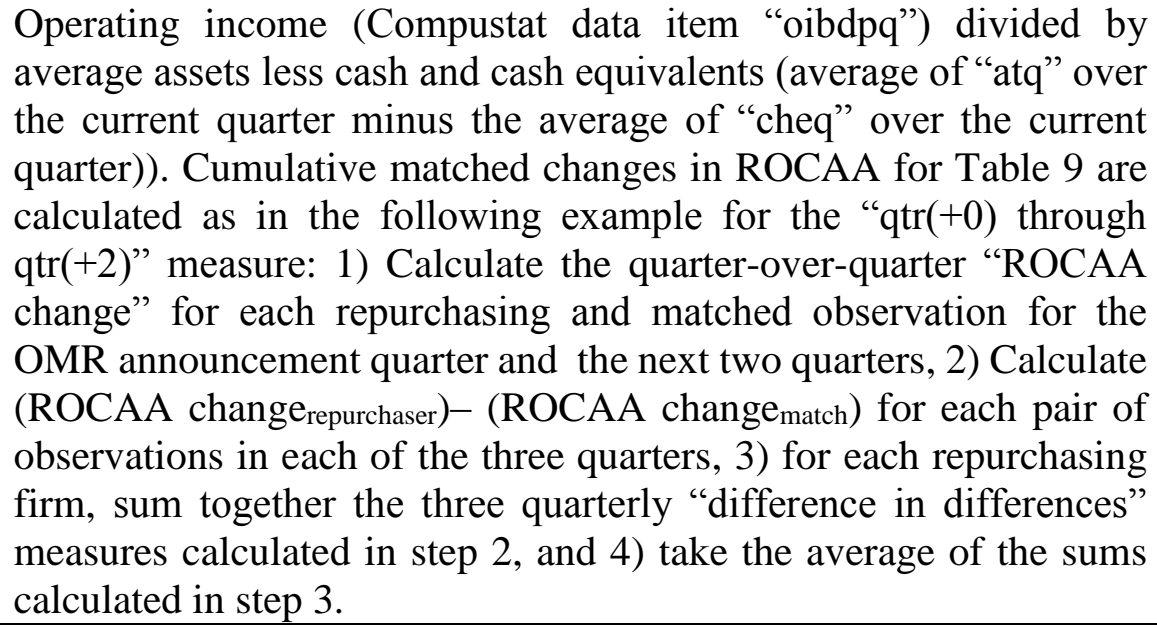 \\
\hline ScaledCapEx & $\begin{array}{l}\text { The sum of all capital expenditures (Compustat data item "capxq") } \\
\text { over the prior four quarters divided by average assets less cash and } \\
\text { cash equivalents (average of "atq" over the current quarter minus the }\end{array}$ \\
\hline
\end{tabular}




\begin{tabular}{|l|l|}
\hline & $\begin{array}{l}\text { average of "cheq" over the current quarter)) over the prior four } \\
\text { quarters. }\end{array}$ \\
\hline UpwardEPS & $\begin{array}{l}\text { The fraction of firm } i \text { 's year-over-year actual EPS changes over its } \\
\text { I/B/E/S listing period that are EPS increases. The variable is } \\
\text { designed to capture how often each firm is "growing" or "shrinking" }\end{array}$ \\
$\begin{array}{l}\text { EPS over the relevant reporting period; an UpwardEPS equal to 0.5 } \\
\text { indicates that a firm has an equal number of periods of EPS growth } \\
\text { and EPS decline over its history. The EPS measure used is } \\
\text { Compustat data item "epsfxq". }\end{array}$ \\
\hline
\end{tabular}


VITA 
VITA

William J. O’Brien

\section{Academic Positions}

Lecturer (tenure-track convertible), University of Illinois at Chicago, June 2015 - present

\section{$\underline{\text { Education }}$}

Ph.D., Finance, expected December 2015 Purdue University, West Lafayette, IN

M.S., Economics, August 2013 Purdue University, West Lafayette, IN

M.B.A., May 2010 (summa cum laude) University of Notre Dame, Notre Dame, IN

B.S., Finance, May 2000 (cum laude) University of Illinois, Urbana, IL

\section{$\underline{\text { Scholarly Interests }}$}

Research: Empirical Corporate Finance (Corporate Governance, International Finance, Executive Compensation, Tax Havens)

Teaching: Corporate Finance, Investments, International Finance, Risk Management and Insurance, Banking and Financial Services

\section{Working Papers}

Detecting Earnings Information in Repurchase Announcements Using the Luck of the (Double) Irish

Option Repricing, Corporate Governance, and the Effect of Shareholder Empowerment (with Huseyin Gulen)

Business Groups and Internal Labor Markets (with Mara Faccio)

Foreign Tax Havens and Domestic Acquisitions (with Jeremiah Harris) 
Captive Finance and Firm Competitiveness (with Andriy Bodnaruk and Andrei Simonov)

$\underline{\text { Works in Progress }}$

Firm Valuation, Ownership, and Shareholder Protection

Time Series Momentum, Reversal, and Earnings Management (with Chengxi Yin)

Teaching Experience

University of Illinois at Chicago, College of Business

MGMT 301 (Introduction to Managerial Finance), Fall 2015.

Purdue University, Krannert School of Management

MGMT 310 (Financial Management), Summer 2013 and Spring 2015.

Teaching evaluations: 4.78/5 (Summer 2013), 4.29/5 (Spring 2015)

Honors, Grants, and Awards

Krannert Certificate for Outstanding Teaching, 2015

SFA Annual Meeting Outstanding PhD Student Paper, 2014

Selected for FMA Doctoral Student Consortium, 2014

Krannert Certificate for Distinguished Teaching, 2014

Robert W. Johnson Award for Distinguished Research Proposal, 2013

Purdue Research Foundation Grant, Purdue University, 2013-2014

John R. Malone Award, Traditional MBA, University of Notre Dame, 2010

1st Place Team, Leeds Net Impact MBA Case Competition, 2010

2nd Place Team, Aspen Institute Business \& Society International MBA Case

Competition, 2010

University of Notre Dame Fellowship, 2009

Allstate Chairman's Award, 2002 \& 2009

Conference Participation

American Economic Association (presenter, scheduled), 2016 
China International Conference in Finance (presentation by co-author), 2013

Financial Management Association Doctoral Student Consortium (presenter), 2014

Financial Management Association (presenter), 2014

Financial Management Association (discussant), 2013, 2014

Southern Finance Association (presenter), 2014

Southern Finance Association (discussant), 2014

\section{Professional Experience}

Allstate Insurance Company Hauppauge, NY and Northbrook, IL

Regional Financial Consultant / Financial Division Manager 2005-2009

Financial Manager / Financial Analyst 2000-2005

Key responsibilities and achievements: As a division manager, managed a $\$ 2.4 \mathrm{~B}$ P\&L to four straight years of profitable growth, resulting in operating profits of more than \$1B and controllable expense reductions of \$10M. Supervised, trained and mentored a team of up to ten Financial Analysts. Designed and implemented innovative sales incentives for Allstate agents and sales managers. Averaged a 94\% favorable rating on employee leadership and engagement surveys over my four years as a manager. My division consistently ranked in the top quartile of all fourteen regional finance divisions across seven core capabilities (Talent Management, Governance, Forecasting and Planning, Measurement and Action, Business Cases, Capital Management, and Consulting and Collaboration). Led the planning, forecasting, and analysis for the \$17B Standard Auto product, the company's largest and most profitable business segment. Created exhibits and commentary for the Management Discussion \& Analysis section of 10-Qs and 10-Ks. Sole author of a cost-benefit analysis which resulted in $\$ 48 \mathrm{M}$ of new funding for the expansion of the firm's internet sales and call-center operations. Collaborated with a team to build an enterprise-level dynamic capital allocation model using Microsoft Excel, Crystal Ball, and Monte Carlo simulations. Coordinated and led the enterprise-wide expense planning process. 